\title{
The Hippo Pathway in Prostate Cancer
}

\author{
Omar Salem ${ }^{1,2}$ and Carsten G. Hansen ${ }^{1,2, *}$ \\ 1 Queen's Medical Research Institute, University of Edinburgh Centre for Inflammation Research, \\ Edinburgh bioQuarter, 47 Little France Crescent, Edinburgh EH16 4TJ, UK; omar.m.salem@ed.ac.uk \\ 2 Institute for Regeneration and Repair, University of Edinburgh, Edinburgh bioQuarter, 5 Little France Drive, \\ Edinburgh EH16 4UU, UK \\ * Correspondence: carsten.g.hansen@ed.ac.uk
}

Received: 19 March 2019; Accepted: 19 April 2019; Published: 23 April 2019

\begin{abstract}
Despite recent efforts, prostate cancer (PCa) remains one of the most common cancers in men. Currently, there is no effective treatment for castration-resistant prostate cancer (CRPC). There is, therefore, an urgent need to identify new therapeutic targets. The Hippo pathway and its downstream effectors - the transcriptional co-activators, Yes-associated protein (YAP) and its paralog, transcriptional co-activator with PDZ-binding motif (TAZ) - are foremost regulators of stem cells and cancer biology. Defective Hippo pathway signaling and YAP/TAZ hyperactivation are common across various cancers. Here, we draw on insights learned from other types of cancers and review the latest advances linking the Hippo pathway and YAP/TAZ to PCa onset and progression. We examine the regulatory interaction between Hippo-YAP/TAZ and the androgen receptor (AR), as main regulators of PCa development, and how uncontrolled expression of YAP/TAZ drives castration resistance by inducing cellular stemness. Finally, we survey the potential therapeutic targeting of the Hippo pathway and YAP/TAZ to overcome PCa.
\end{abstract}

Keywords: hippo pathway; YAP/TAZ; prostate cancer; castration resistance; signal cross-talk; feedback loops

\section{Introduction}

Prostate cancer (PCa) is worldwide one of the most prevalent cancers in men, with over one million new cases reported annually [1,2]. Initially, premalignant prostatic intraepithelial neoplasia (PIN) lesions form, which develop into advanced localized PCa followed by metastasis $[3,4]$. The prostate gland consists of luminal, basal, and neuroendocrine cells embedded in fibromuscular stroma (Figure 1) [4,5]. The most commonly reported $\mathrm{PCa}$ is acinar adenocarcinoma, which is androgen receptor (AR)-positive and arises from the prostate gland secretory luminal cell lineage [4,5]. A smaller subset of PCa develops from the neuroendocrine cell lineage [4,5]. Neuroendocrine tumors are classified as small-cell carcinoma and are more prevalent following recurrence [4,5] (Figure 1).

Early stages of prostate cancer are managed by surveillance, as well as classical approaches such as radiation therapy and surgery [6,7]. However, the first line of treatment of locally advanced or metastatic prostate cancer is androgen deprivation therapy (ADT) [8-10]. Although ADT is effective initially, patients develop castration-resistant prostate cancer (CRPC) within 1-3 years. CRPC is defined as PCa that progressed despite castrate serum testosterone levels $(<50 \mathrm{ng} / \mathrm{dL})[11,12]$.

Clinical management of CRPC is challenging, which is partly due to the molecular variation between patients [13]. Several mechanisms activate AR in CRPC patients [12,14]. These include AR mutations and amplification, which leads to AR hypersensitivity or promiscuity, causing the activation of AR in response to low androgen levels and non-androgenic steroids $[15,16]$. PCa expressing some AR splice variants also overcomes ADT. These alternative AR variants are constitutively active due to the loss of the C-terminal part of the AR ligand-binding domain [14,17]. Additionally, CRPC patients 
have relatively higher androgen levels compared to healthy males [18], which is due to intratumoral steroidogenesis, as well as altered adrenal steroid production $[18,19]$. Notably, ligand-independent activation of AR also plays prominent roles in CRPC [20]. Despite recent efforts to optimize current ADT strategies, CRPC remains a global burden. Advanced PCa is characterized by poor prognosis and high mortality rate, causing approximately 350,000 global deaths annually $[1,2]$. There is, therefore, an urgent need to unravel the complex mechanism underlying PCa development, progression, and ADT resistance in order to identify new druggable targets.

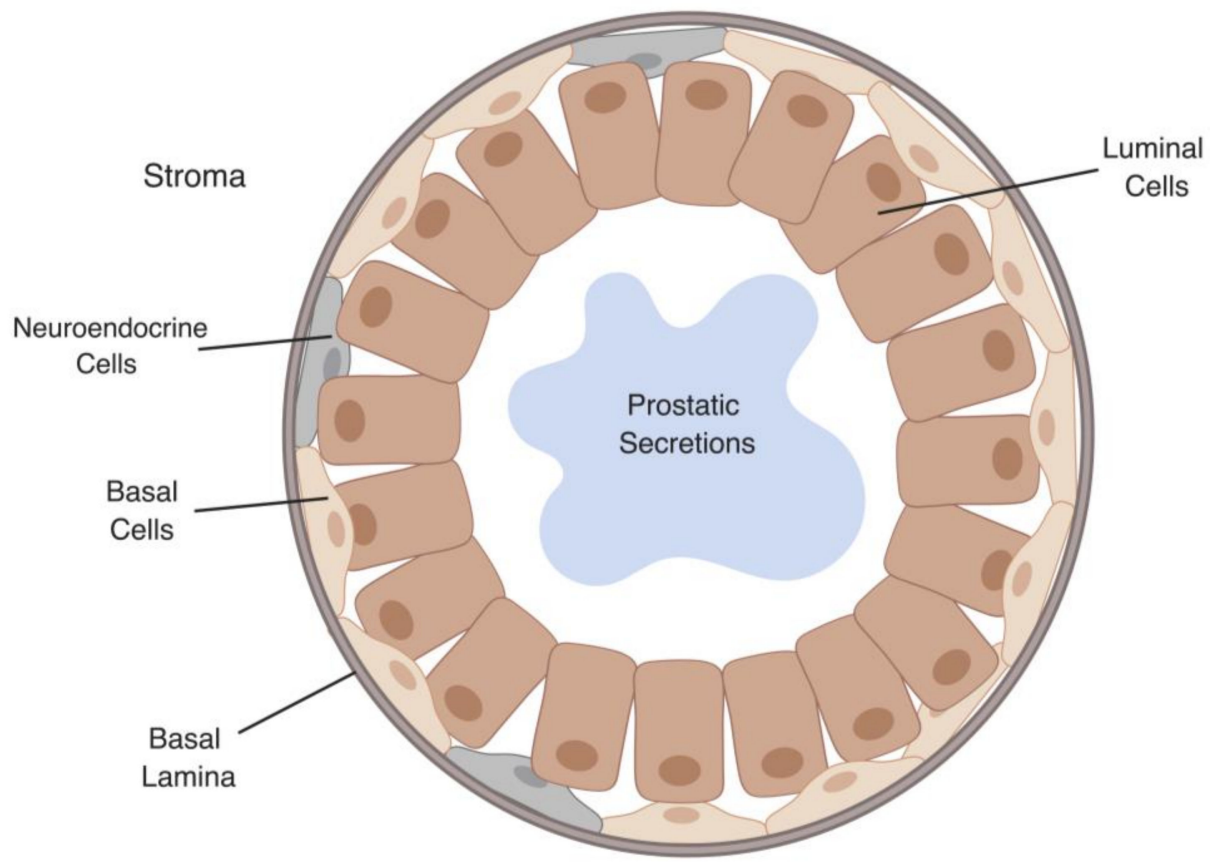

Figure 1. Representation of different cell types in the prostate gland.

The Hippo signaling pathway is a major player in stem cells and cancer biology [21,22]. The Hippo signaling cascade, identified through studies of tumor suppressors in the fruitfly, Drosophila melanogaster [23], is conserved across species, including humans [24]. It acts as a crucial regulator of cell growth and proliferation, organ development, cellular homeostasis, and regeneration [22,25]. The Hippo pathway is regulated by multiple signals such as, cell-density/polarity, mechanotransduction, nutrients, and via G-protein-coupled receptors [26-29]. Importantly, apparent kinase cascade independent regulation of Yes-associated protein (YAP)/ transcriptional coactivator with PDZ-binding motif (TAZ) also takes place [30-32] (Box 1). The upregulation of the Hippo pathway downstream effectors, YAP/TAZ, is central in a variety of solid tumors $[21,25,29,33,34]$. Prominently, the implications of elevated activity of YAP/TAZ in prostate cancer $(\mathrm{PCa})$ are becoming apparent.

In this review article, we summarize the expanding evidence linking YAP and TAZ to PCa development, hormone inhibition resistance, and metastasis. Additionally, we highlight the role of the Hippo pathway in regulating prostate cancer stem cells and the importance of Hippo-YAP/TAZ as a potential therapeutic target for PCa, and we stress hitherto outstanding questions of how the dysregulated Hippo pathway drives PCa onset and development. 
Box 1. Yes-associated protein (YAP)/PDZ-binding motif (TAZ) Regulation by the Canonical Hippo Pathway.

\begin{abstract}
The Hippo pathway consists of an upstream serine-threonine kinase cascade. The chief kinases are MST1/2 (the mammalian Hippo homolog) and the MAP4K family of kinases, which phosphorylate and, in turn, activates large tumor suppressor (LATS1/2) [35-45]. When the Hippo kinases are "active", LATS1/2 phosphorylate and thereby inhibit the transcriptional co-activator YAP [46] and its paralog TAZ [47], causing their cytoplasmic retention by protein 14-3-3, AMOT, or degradation [30,48-51]. In contrast, when the kinase module is "inactive", dephosphorylation of YAP/TAZ occurs, which allows YAP/TAZ to translocate to the nucleus and regulate transcription. YAP/TAZ-mediated transcriptional regulation is predominantly via direct binding to the transcription factors TEAD1-TEAD4 [52-54]. As a consequence, the expression of multiple proliferative and antiapoptotic genes occurs, such as connective tissue growth factor (CTGF) and cysteine-rich angiogenic factor (CYR61) [52-54]. Additional kinases were also shown to directly phosphorylate and thereby regulate YAP/TAZ, such as SRC [55-58], Nuclear Dbf2-related 1/2 (NDR1/2) [59], c-Jun N-terminal kinase (JNK) [60,61], 5 ' adenosine monophosphate-activated protein kinase (AMPK) [62-64], and Nemo-like kinase (NLK) $[65,66]$. Finally, kinase-independent regulation of YAP/TAZ is also taking place [30-32].
\end{abstract}

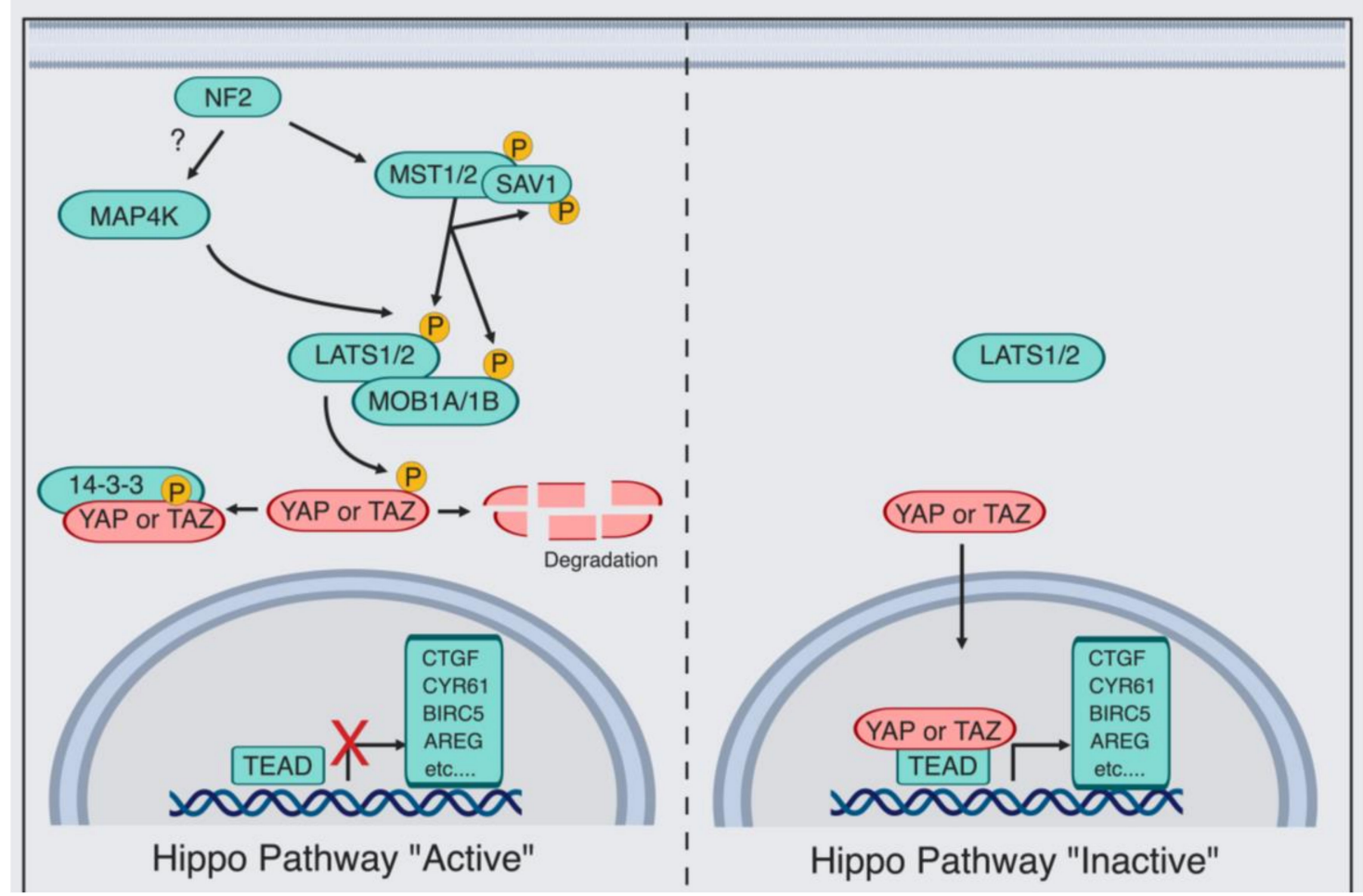

\title{
2. Hippo/YAP Key Players in Early Stages of Prostate Cancer
}

Elevated YAP activity is observed in most solid tumors [34], and hyperactive YAP induces the formation of several carcinomas including liver, lung, breast, sarcoma, and pancreas [21,22,33,67]. YAP is also identified as a clinical marker for PCa progression [68] and regulator of CRPC [69]. YAP levels correlate with patients' Gleason score, prostate-specific antigen (PSA) levels, and extraprostatic extensions [68,70] (Figure 2).

Additionally, exogenous overexpression of YAP in normal prostate epithelial cells induces colony formation and increased migration in three-dimensional (3D) cultures [71]. How YAP becomes hyperactivated and drives PCa initiation and development is currently not clear, but several mechanisms were recently implicated (Figure 3). 


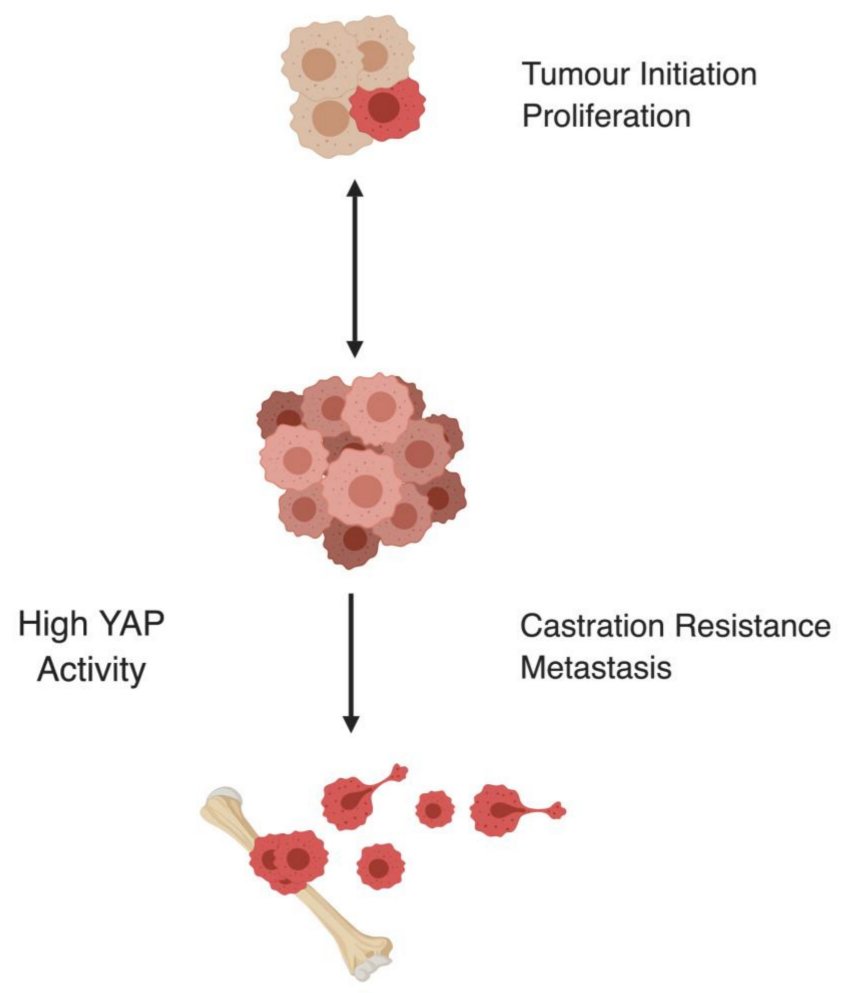

Figure 2. Schematic overview of YAP activity levels across different stages of prostate cancer (PCa). YAP regulates multiple stages of PCa $[68,70,71]$.

\subsection{E26 Transformation-Specific (ETS) Transcription Factors}

ETS-regulated gene (ERG) is a transcription factor that belongs to the E26 transformation-specific (ETS) family and drives proliferation, apoptosis, and angiogenesis [72]. ERG overexpression in PCa results due to the fusion on chromosome 21q22 between the first exon of the androgen regulated gene TMPRSS2 and the coding sequence of ERG [72,73]. This is a relatively frequent translocation, present in approximately $40-50 \%$ of PCa patients [74]. ERG overexpression results in the development of PCa tumors in aged mice [75]. Mechanistically, ERG induces YAP promoter activity in the hormone refractory PCa cell model (VCaP cells) [76], and ERG knockdown results in a decrease in YAP protein levels [75] (Figure 3). ERG both transactivates TEAD4 and directly binds to the CTGF promoter region, thereby inducing CTGF expression [75]. ETV1, an additional member of the ETS transcription factors, induces YAP expression in LNCaP cells by recruiting the lysine-specific demethylase (JMJD2A) to the YAP promoter [77] (Figure 3). ETV1-induced YAP expression in vivo causes PIN lesion formation, which, when combined with a single copy loss of phosphatase and tensin homolog (PTEN), progresses to malignant carcinoma [77]. PTEN is a negative regulator of the phosphoinositide 3-kinase/protein kinase B (PI3K/AKT) pathway, which controls proliferation and apoptosis [78]. PTEN deletions are identified in around $20 \%$ of primary PCa and $50 \%$ of advanced PCa [79].

\subsection{Polarity Protein (Par3)}

Epithelial cells are polarized cells with distinct functional apical and basolateral membrane domains [80]. Par3, among other polarity proteins, is a major regulator of epithelial cell structure and function [81,82]. Moreover, loss of Par3 is present in a variety of epithelial tumors [82]. Par3 loss leads to the formation of high-grade PIN lesions in vivo due to high YAP activity [82]. In this context, Par3 interrupts the NF2-derived recruitment of LATS1 to the plasma membrane [83]. Additionally, PIN lesions progress to PCa adenocarcinoma when combined with LATS1 loss in the Par3/LATS1 knockout (KO) murine model [83]. Contradictorily, Par3 sequesters the potent Hippo kinase cascade activator, kidney- and brain-expressed protein (KIBRA), and prevents it from forming a complex with NF2 [84]. 
As a result, KIBRA complexes with Par3 and atypical protein kinase C (aPKC). Knockdown of Par3 expression in PCa cells restores LATS1 and YAP phosphorylation levels, resulting in a lower migration rate in vitro and lower rate of metastasis in vivo [84]. The findings from both studies suggest that Par3 expression is lost during tumor initiation, but might be retained in advanced PCa triggering metastasis $[83,84]$ (Figure 3). The regulation of Par3 in PCa is not fully understood and the interplay between the Hippo pathway and polarity proteins in PCa requires further investigation.

\subsection{Heat Shock Proteins}

Heat shock proteins (Hsps) are cellular stress modalities that regulate signaling and homeostasis [85]. Hsp expression is upregulated in response to chemotherapy and hormonal therapy [86]. The heat shock protein 27 (Hsp27) is elevated in a variety of tumors such as lung, breast, and cervical cancers [86]. Hsp27 is utilized by PCa tumor cells to resist apoptosis following androgen deprivation [87]. Hsp27 acts as a regulator of MST1 via promoting its ubiquitin-mediated degradation. As a result, LATS1 and MOB kinase activator 1 (MOB1) phosphorylation are reduced, causing YAP dephosphorylation and nuclear translocation [88] (Figure 3). However, it is worth noting that ablation of both MST1 and MST2 is needed both in vivo and in vitro to generally impair LATS1/2 activation [89-91], and, in some contexts, inhibition of the MAP4K family of kinases is also necessary to reduce overall LATS1/2 activity and thereby to increase YAP activity $[37,42,45]$.

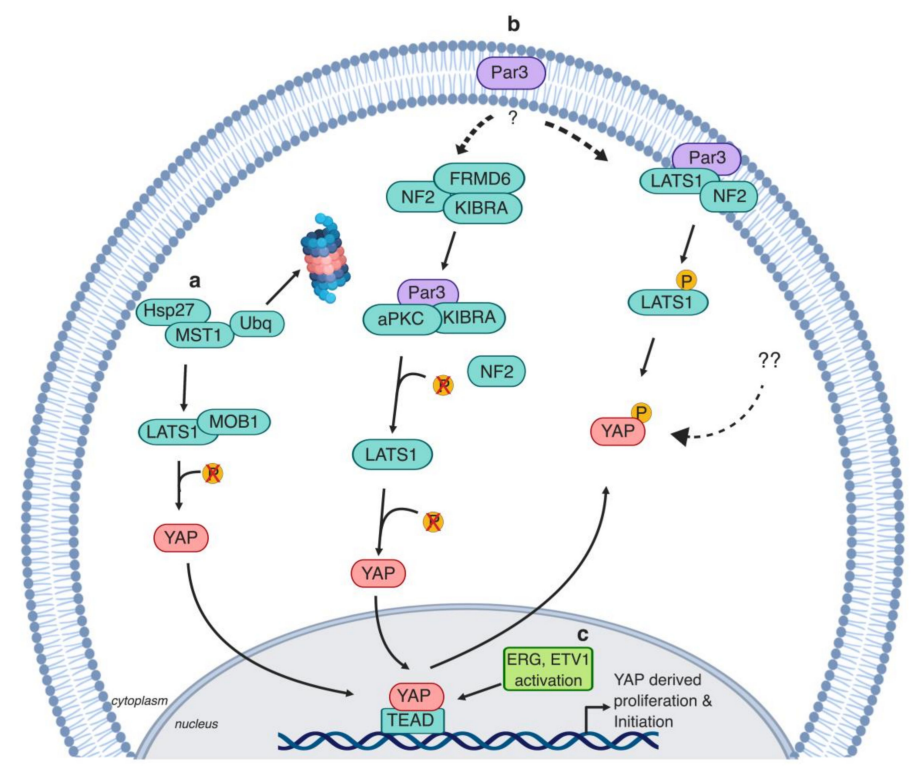

Figure 3. Mechanisms of YAP regulation in early stages of prostate cancer. a. Heat shock protein 27 (Hsp27) induces MST1 ubiquitin-mediated degradation, which in turn causes LATS1 and MOB1 dephosphorylation and thereby inactivation, consequently inducing YAP nuclear translocation [88]. b. Two different mechanisms were proposed by which polarity protein (Par3) regulates YAP; (1) Par3 inhibits YAP activity through inducing the recruitment of Neurofibromatosis type 2 (NF2/Merlin) and LATS1 to the membrane. As a result, LATS1 is activated, which induces YAP phosphorylation and cytoplasmic retention [83]. (2) Par3 induces YAP activation through the dissociation of kidney- and brain-expressed protein (KIBRA) from its canonical complex (KIBRA/NF2/ FERM domain-containing protein 6 (FRDM6)) and drives the recruitment of KIBRA to the Par3/aPKC/KIBRA complex. Thus, the interaction between KIBRA and LATS1 is disrupted, which induces LATS1 dephosphorylation and thereby YAP activation [84]. c. E26 transformation-specific (ETS) transcription factors trigger YAP induction. (1) ETS-regulated gene (ERG) activation drives YAP activation in old aged mice. ERG induces YAP and TEAD4 promoter activity and thereby triggers YAP target gene expression [75]. (2) ETS translocation variant 1 (ETV1) drives YAP activation by recruiting lysine specific demethylase (JMJD2A) to the YAP promoter [77]. 


\section{The Hippo Pathway Promotes Castration Resistance and Metastasis in Prostate Cancer}

\subsection{Androgen Receptor-Regulator of CRPC Progression}

The androgen receptor (AR) is a transcription factor that belongs to the superfamily of steroid receptor hormones [92]. AR signaling is essential for prostate development and homeostasis [93]. During absence of androgens, inactive AR resides in the cytoplasm bound to heat shock proteins [92]. Upon binding of dihydrotestosterone (DHT), AR dissociates and translocates to the nucleus to induce gene expression [92]. AR-mediated gene expression occurs via multiple AR coactivators and AR-mediated recognition of androgen response elements (AREs) on the target gene promoter. AREs consist of two common inverted hexameric half-sites (5'-AGAACA- $\left.3^{\prime}\right)$ separated by three base pairs [94]. In healthy tissue, tight homeostatic androgen signaling between stromal and epithelial cells regulate the prostate gland function [93,95]. Disrupted AR signaling is a key event in PCa initiation, progression, and development of castration resistance $[5,96,97]$. However, to date, the exact molecular mechanism via which CRPC develops is yet to be fully explored [93].

\subsection{AR and YAP Colocalization}

The role of the Hippo pathway in CRPC development and AR regulation recently gained momentum (Figure 4). Coimmunoprecipitation and immunofluorescence microscopy revealed that $\mathrm{AR}$ and YAP colocalize to and interact in the nucleus [98]. This interaction is androgen-dependent in LNCaP cells, but androgen-independent in C4-2 cells [98]. C4-2 cells are a hormone-independent subline of LNCaP cells, representing a clinical CRPC in vitro cell model [99]. Downregulation of YAP signaling results in the suppression of AR target genes, suggesting that YAP is critical for AR activity [98].

Interestingly, C4-2 cells harbor low MST1 kinase signaling, and restoring MST1 expression in these cells results in impeding the YAP-AR nuclear interaction and AR activity $[98,100]$. One plausible mechanism for AR upregulation in CRPC patients is, therefore, MST epigenetic silencing [101]. Cellular myelocytomatosis (c-MYC), a transcription factor that regulates cellular growth and proliferation [102], is commonly overexpressed in PCa patients, which induces tumor initiation [103]. Mechanistically, c-MYC is a regulator of the enhancer of zeste homolog 2 (EHZ2), which is a subunit of polycomb repressive complex 2 (PRC2) [104]. EZH2, a histone methyltransferase, catalyzes the trimethylation of histone 3 at lysine 27 (H3K27me3) to regulate gene expression [105]. EZH2 functions both as a transcriptional activator and repressor for specific gene sets in a cell-context-dependent manner [106]. EZH2 acts as a coactivator of the androgen receptor in CRPC [107]. c-MYC induces EZH2 activity via suppressing microRNA (miR)-26a/b, which results in MST1 promoter silencing [101]. Treating C4-2 cells with JQ1 results in downregulating c-MYC, which in turn induces MST1 expression and decreases cell survival [101]. However, combining MST1 knockdown with either c-MYC inhibition by 10058-F4 or EZH2 inhibition by GSK126 restores cell survival [101].

LATS2 and AR were, using immunohistochemistry, reported to colocalize within healthy prostate epithelium patient samples [108]. When in the nucleus, LATS2 and AR form a protein complex, which binds to prostate-specific antigen (PSA) promoter and enhancer regions [108]. LATS2 suppresses AR activity through hindering the $\mathrm{NH}_{2}$ - and $\mathrm{COOH}$-terminal interaction within the receptor [108]. The activation status of LATS2 was not examined, and whether AR is a direct substrate for LATS2 is unknown; it is, therefore, still an outstanding question if this LATS2-mediated regulation of AR transcription is phosphorylation-dependent [108]. Importantly, LATS2 levels negatively correlate with PCa tumor stage, a conserved phenomenon with several other types of carcinomas [108-110]. Paradoxically, LATS2 is in a range of cell types and, in vivo, a YAP/TAZ-TEAD target gene [111-113], which forms an integral component of a feedback loop that keeps YAP/TAZ-TEAD activity levels in check [111-113]. Loss of LATS2 expression, but high YAP activity $[75,98]$ and, therefore, impaired Hippo pathway feedback in high-grade PCa might, therefore, be a defining PCa hallmark. The relatively low LATS2 levels in PCa might be due to additional YAP/TAZ-TEAD-independent transcriptional 
regulation and/or post-transcriptional regulation of LATS2 protein. It will be critical to establish if negative feedback loops within the Hippo pathway are prevalent in healthy prostates and, if so, why these dynamic negative feedbacks might be defective in PCa. Therapeutically reinstating these negative feedback loops within the Hippo pathway might then be a viable option. Overall, these reports show that the Hippo kinase cascade and its effector YAP are regulators of AR nuclear localization and activity.

\subsection{The Hippo Pathway, Tumor Microenvironment, and Immune Response Evasion}

Cross-talk between the Hippo pathway and the tumor microenvironment is widespread across multiple solid tumors and regularly operates via a feed-forward loop that drives tumor progression $[21,26,114,115]$. YAP/TAZ is a signaling nexus and regulates cell-cell interaction and cell-stroma interaction through inducing the expression of a range of secretory proteins such as CYR61 and CTGF $[31,54,115,116]$, as well as of components essential for mechanoresponsive plasma membrane organelles such as caveolae [117], and components and regulatory elements of focal adhesions such as integrins and cytoskeletal tension [54,118-122]. YAP/TAZ are well-established molecular sensors of the extracellular matrix (ECM), and both sense the stiffness and composition of the ECM $[31,115,118]$. In vitro experiments show that cells cultured on high ECM matrix stiffness result in increased YAP/TAZ nuclear localization and target gene expression $[31,115,116,123,124]$. In comparison, cells grown on low ECM stiffness have a higher cytoplasmic fraction of YAP/TAZ [31,115,116,123,124]. This is particularly important in PCa, as PCa is widely recognized for its rich tumor-stroma interaction $[125,126]$.

Downregulation of $\alpha 3$ integrin causes PCa progression and promotes formation of metastatic lesions via altering YAP/TAZ activity. Mechanistically, loss of $\alpha 3 \beta 1$ in PCa results in the inhibition of the Abelson-related gene (Arg/abl2) tyrosine kinase cascade, which dephosphorylates the p190Rho-Guanosine triphosphate (GTP)ase activating protein-(GAP)/p120RAS-GAP (p190RhoGAP/ p120RAS-GAP complex [127]. Consequently, Rho signaling is activated, ultimately causing increased YAP/TAZ levels, which promotes cellular migration in vitro and metastasis in vivo [127]. However, it is not entirely clear whether RhoA in this instance acts via the Hippo-LATS kinase cascade or independently from it. Paradoxically, $\alpha 3 \beta 1$ loss inhibited skin tumorigenesis in vivo [128]. Importantly, ECM regulates multiple cellular cancer properties [129] and it remains unclear whether these effects are mediated via the Hippo pathway in PCa and importantly whether ECM stiffness is inducing YAP activity in PCa. Addressing these questions might partly explain the increased YAP expression levels in PCa patients.

The ability of tumor cells to evade immune response is widely recognized to be a hallmark of cancer progression [130]. Intriguingly, YAP is partly responsible for this in PCa [131]. In a PTEN/ SMAD4 knockout PCa mouse model, YAP levels are elevated [131]. In this model, YAP expression results in myeloid-derived suppressor cell (MDSC) recruitment via the CXCL5/CXCR2 axis. MDSCs mediate tumor immune response evasion through suppressing T-cell activation, proliferation, and viability [132]. YAP-TEAD directly binds to the CXCL5 promoter, inducing CXCL5 expression. Either MDSC depletion, or inhibition of YAP or CXCL5/CXCR2 activity halts tumor progression [131]. Similarly, YAP hyperactivation is observed in the Kras/p53 knockout pancreatic cancer mouse model, which stimulates chemokines expression and thereby recruitment of MDSCs to tumors [133]. Of note, YAP governs the recruitment of tumor-infiltrating type II macrophages (M2) in liver carcinoma, which promotes tumorigenesis by avoiding immune clearance [134] (Figure 4). However, how the Hippo pathway gets dysregulated and drives PCa tumor-stroma interactions is still not fully understood.

\subsection{TAZ's Role in Metastasis}

YAP and TAZ are modulators of cell motility and cytoskeletal dynamics in a feedback dependent manner [119]. TAZ in particular is a potent regulator of epithelial-mesenchymal transition (EMT) in most types of solid cancers, including ovarian cancer, glioma, and breast cancer [135-140]. The role of TAZ in PCa tumor progression and the regulatory nature between TAZ and AR is not well described. 
TAZ overexpression induces malignant transformation of the non-cancerous prostate epithelial cells, RWPE-1 [141]. Knockdown of TAZ in PCa cells causes reduction in migratory rate in two-dimensional (2D) cultures, as well as lower metastatic rate when injected in vivo. Endogenous expression of TAZ is regulated by ETS transcription factors members ETV1/4/5 (Figure 4) [141]. ETV1/4/5 induce TAZ gene expression, which results in the expression of SH3 domain-binding protein 1 (SH3BP1) via TAZ-TEAD. SH3BP1 belongs to the RhoGAP protein family and regulates Rac signaling to modulate cytoskeletal dynamics and cell motility [142]. So far, the PCa stage-specific levels of TAZ in PCa tumor samples are yet to be investigated.

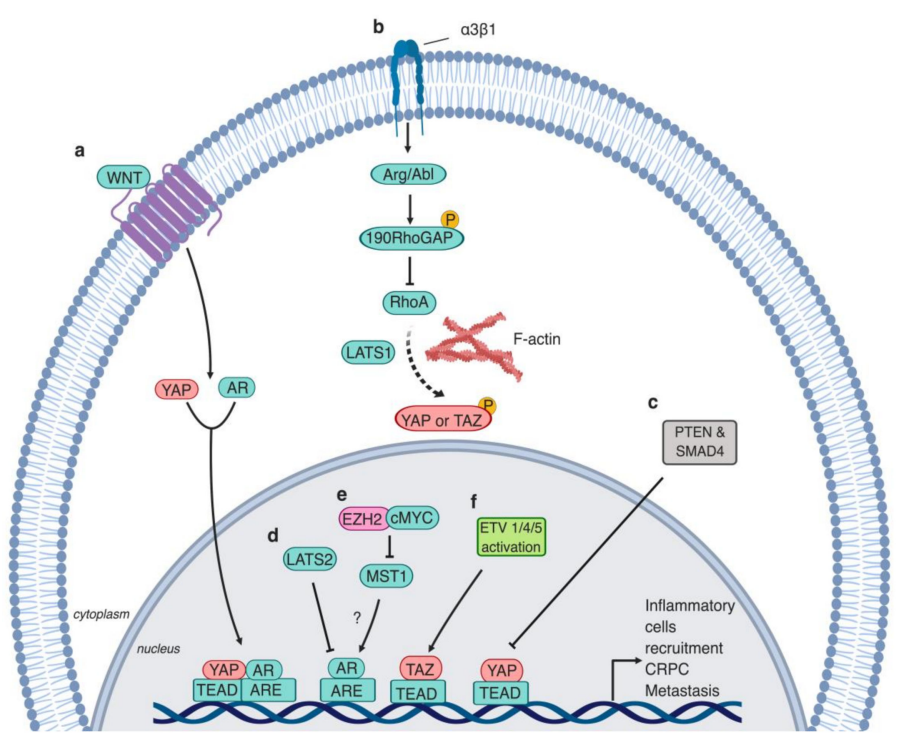

Figure 4. The Hippo pathway regulation of advanced prostate cancer. a. During androgen deprivation, Wingless (WNT) signaling drives the nuclear translocation of YAP and AR, resulting in YAP and AR target gene induction [143]. Additionally, YAP and AR colocalize in the nucleus and induce gene expression independently from WNT signaling or androgen availability [98]. b. $\alpha 3 \beta 1$ integrin stimulates the kinase activity of Arg/Abl, which phosphorylates 190RhoGAP, resulting in the inhibition of RhoA GTPases. Consequently, YAP/TAZ are phosphorylated via LATS1 activity and/or actin rearrangement and retained in the cytoplasm. $\alpha 3 \beta 1$ loss results in the disruption of this signaling cascade, inducing prostate cellular migration and metastasis [127]. c. PTEN and SMAD4 activity loss results in YAP hyperactivation. YAP signaling induces the recruitment of inflammatory cells [131]. d. LAST2 impedes AR receptor activity and restricts the binding of AR to the prostate-specific antigen (PSA) promoter [108]. e. EZH2 and c-MYC cooperate to induce methylation and silencing of MST1, which might induce AR activity [101]. g. ETV1/4/5 activate TAZ, triggering metastasis via the induction of SH3BP1 [141].

\section{The Hippo Pathway's Role in Prostate Cancer Stem Cells}

The development of CRPC following androgen deprivation therapy (ADT) is often inevitable [144]. CRPC likely develops from the prostate cancer stem cells (PCSCs), a subset of cells within the tumor which regulate initiation, but importantly also recurrence [145]. PCSCs were successfully isolated from patient tissue samples on the basis of their $\alpha_{2} \beta_{1}{ }^{\text {hi }} \mathrm{CD} 133^{+} \mathrm{CD} 44^{+}$phenotype [146-149]. PCSCs have a high proliferation rate and increased ability of colony formation in 3D cultures, as well as an ability to form prostate-like structures when injected in immunocompromised mice compared to CD44and CD133- cells [146-149]. The Hippo pathway regulates cancer stem cells (CSCs) within a variety of tumors [136,150,151]. Interestingly, PC3 and DU145 cells resistant to the chemotherapeutic agent docetaxel possess a CD44 ${ }^{+}$phenotype. In this context, CD44 increases cellular migration rate in 2D cultures via inducing YAP, CYR61, and CTGF expression [152]. 
The stemness regulator microRNA, cluster miR-302-367, downregulates LATS2, which results in YAP dephosphorylation and nuclear translocation [153]. Additionally, miR-302-367 overexpression in LNCaP cells induces their capacity to form spheres in 2D cultures and xenograft tumors when injected into castrated mice [153]. Cyclic guanosine monophosphate (cGMP)-specific phosphodiesterase type 5 (PDE5) also induces stemness via the Hippo pathway [154]. Pharmacological PDE5 inhibition or inhibition via endogenous nitric oxide results in the activation of cGMP-dependent protein G (PKG); this activates MST1/LATS1 phosphorylation causing TAZ cytoplasmic retention and degradation [154]. AR further inhibits the transcriptional activity of YAP in LNCaP, as well as in the serially propagated castration-induced regression derived 22rv1 cells. Mechanistically, AR complexes with EZH2 and DNA methyltransferase 3 (DNMT3a) at the YAP promoter, causing its methylation and silencing [155]. In this sense, during androgen deprivation therapy, AR inhibition results in YAP transcriptional activation. YAP expression results in the transcription of stemness-stimulating genes in a TEAD-dependent manner, which induces sphere formation in vitro [155]. Additionally, inhibiting YAP activity in vivo prevents PCa recurrence in castrated TRAMP mice [155] (Figure 5).

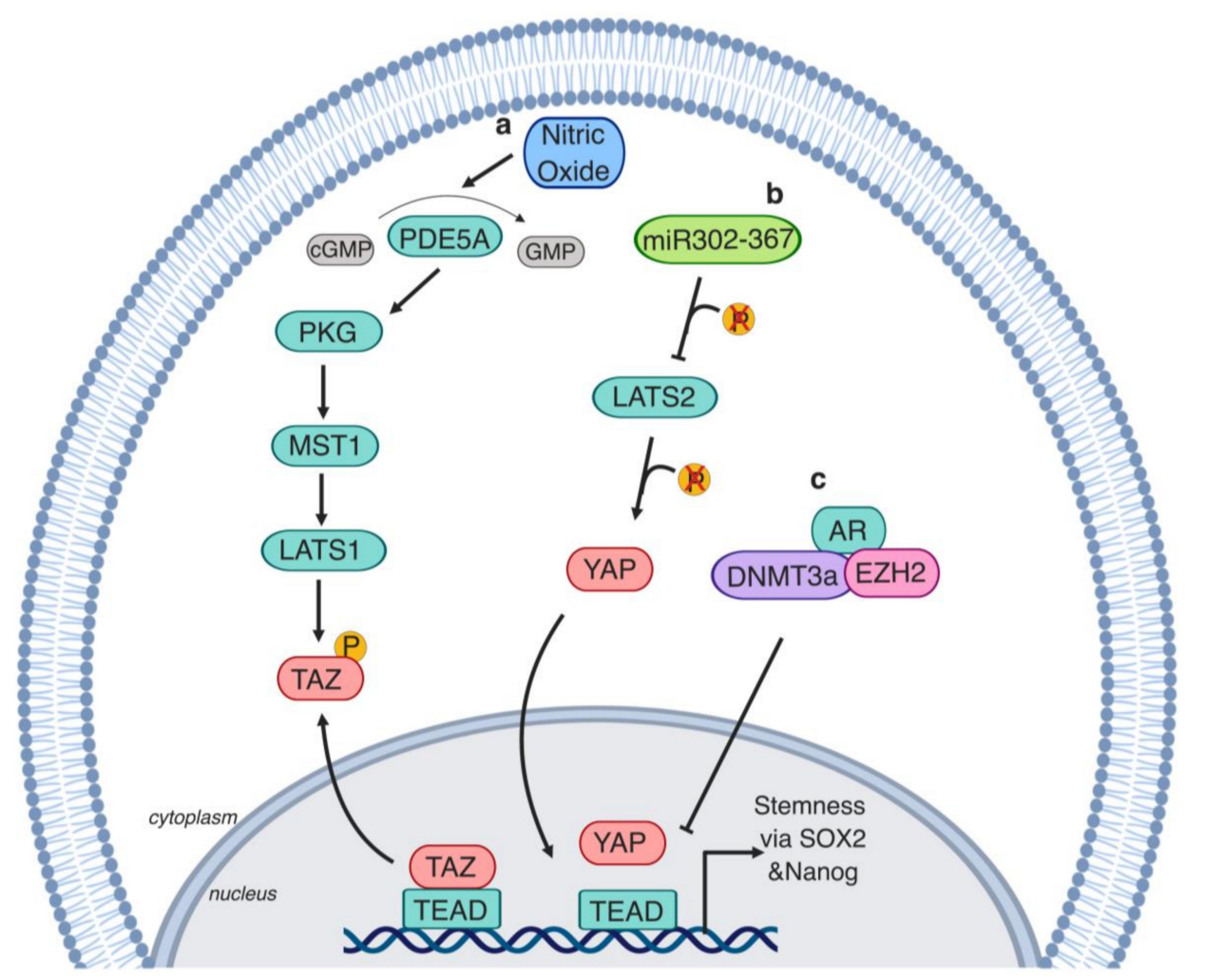

Figure 5. YAP/TAZ regulate prostate cancer stem cells (PCSCs). a. Inhibition of the stemness regulator cyclic GMP-specific phosphodiesterase type 5 (PDE5) by nitric oxide causes activation of cGMP-dependent protein G (PKG), which activates MST1/LATS1 and causes TAZ phosphorylation [154]. b. Stemness regulator microRNA (miR)-302-367 cluster induces LATS2 dephosphorylation which results in YAP nuclear translocation [153]. c. DNMT3a and EZH2 form a heterotrimeric complex with AR, which translocates to the YAP promoter inducing its silencing [155].

\section{Targeting the Hippo Pathway for Prostate Cancer Therapy}

\subsection{Targeting $Y A P / T A Z-T E A D$}

The Hippo pathway is a critical regulator of several hallmarks of PCa. Targeting Hippo-YAP/TAZ clinically, therefore, has therapeutic potential. As YAP/TAZ are transcriptional coactivators that principally function via binding to the TEAD family of transcription factors [52,53,156-158], the most direct route to target the Hippo pathway is via this interaction [158]. Verteporfin is a small-molecule 
inhibitor of this YAP/TAZ-TEAD interaction [159]. Verteporfin suppresses CRPC tumor growth and PCSC proliferation, which ultimately also prevents recurrence $[75,98,155]$. Although Verteporfin is used for macular degeneration treatment, its future use for cancer therapeutics is hampered by Verteporfin's low solubility and low target affinity, which makes it generally toxic $[160,161]$. Vestigial-like 4 (VGLL4) is a tumor suppressor that competitively binds to TEAD via its tondu domain (TDU), thereby preventing YAP from mediating transcription [162,163]. VGLL4-mimicking peptide (super TDU) abrogates YAP binding to TEAD4, which has anti-tumor effects in gastric cancer patient-derived cells and in vivo in the gastric cancer mouse model driven by Helicobacter pylori infection [164]. A YAP-like peptide (17-mer) was designed aiming to impede YAP-TEAD binding. The 17-mer peptide has higher affinity for TEAD1 compared to YAP $[165,166]$. Although targeting the YAP-TEAD interaction appears to be the most straightforward route toward targeting the Hippo pathway, to date, none of the discovered agents are approved for cancer therapeutics.

\subsection{Statins}

Statins are a class of US food and drug administration (FDA)-approved drugs for hypercholesterolemia treatment [167]. Statins inhibit the enzyme, 3-hydroxy-3-methyl-glutarylcoenzyme A (HMG-CoA) reductase, which prevents the conversion of HMG-CoA to mevalonic acid [168]. Subsequently, statins reduce the synthesis of geranylgeranyl pyrophosphate, which is required for Rho GTPase activity $[169,170]$. Statins induce YAP phosphorylation through Rho GTPase activity and actin rearrangement $[169,170]$. In vitro, statins induce gap 1 (G1) cell-cycle arrest and apoptosis in the PCa cell line, C4-2B [171]. Importantly, retrospective studies in a large Taiwanese cohort of statin-treated heart disease patients showed decreased incidence of PCa [172]. Furthermore, statins were recently identified to reduce PCa aggressiveness and metastasis incidence significantly in a retrospective study of a large cohort of Saskatchewan men [173]. Similarly, the occurrence of breast, ovarian, colorectal, and liver cancer is also reported to be lower in statin users [167]. Nonetheless, it remains unclear whether this statin-based clinical manifestation is mediated via the Hippo pathway.

\subsection{Hippo Kinase Activators}

The rapidly accelerated fibrosarcoma (RAF) family of serine/threonine kinases acts upstream of the MST kinases [174]. RAF-1 suppresses apoptosis by sequestering and preventing MST2 phosphorylation [174]. Inhibition of RAF-1, therefore, results in the activation of MST2. ISIS 1532 oligonucleotide was designed to target the $3^{\prime}$ untranslated region of cRaf messenger RNA (mRNA) $[175,176]$. In preclinical trials, ISIS 1532 inhibited lung carcinoma in in vivo mouse models $[175,176]$. However, three phase II clinical trials in patients with advanced PCa, and ovarian and colon cancers showed no significant response, and the agent was withdrawn from further testing [176-179]. Targeting the Hippo pathway kinases proves challenging as it is regulated by a variety of external cues and interacts with multiple signaling pathways [161]. In essence, activators of the YAP/TAZ inhibitory kinases are needed, and designing kinase activators is in general more challenging than inhibitors $[180,181]$.

\section{Signaling Cross-Talk between the Hippo Pathway and Multiple Signaling Pathways}

\subsection{WNT Receptor Signaling}

Upon androgen deprivation, WNT signaling stimulation triggers the nuclear translocation of AR and YAP to the nucleus, which induces AR-mediated gene expression independently from $\beta$-catenin translocation [143] (Figure 4). YAP and TAZ are downstream effectors of WNT/ $\beta$-catenin [182,183]. Upon WNT stimulation, YAP and TAZ are released from the WNT destruction complex and translocate to the nucleus to induce transcription [182,183]. Additionally, WNT-mediated activation of YAP/TAZ can occur independently from $\beta$-catenin via the scaffold protein, adenomatous polyposis coli (APC), which facilitates SAV1 and LATS1 phosphorylation via glycogen synthase kinase $3 \beta$ (GSK-3 $\beta$ ) 
activity [184]. Importantly, APC activation mutations are reported in 5\% of PCa patients [185]. Contradictorily, knockout of APC in vivo in mouse models results in prostate tumor formation [186]. Impressive work using an array of CripsR knockout cell lines, as well as mouse models, showed that alternative WNT signlling (Wnt5a/b) activates YAP/TAZ via GPCR $\alpha 12 / 13$; these G-coupled proteins signal to activate RhoGTPases that inhibit LATS1/2 activity [139,187]. Whether APC or alternative WNT signaling activates YAP/TAZ in PCa and whether this mechanism is mediated via androgen receptor signaling remains unexplored.

\subsection{Mechanistic Target of Rapamycin (mTOR) Signaling}

The mTOR protein is a central cell growth regulator, which is regulated by growth factors, energy levels, and nutrients. When active, mTOR stimulates biosynthetic pathways including nucleotide, protein, and lipid synthesis, while inhibiting catabolic processes, such as autophagy [188,189]. Intriguingly, PCa tumor cells with high PI3K/AKT/mTOR activity are proposed as a mechanism for prostate tumors to surpass hormone inhibition therapy [190-192]. Additionally, speckle-type POZ (pox virus and zinc finger protein) protein (SPOP) mutations, the most common mutations in primary $\mathrm{PCa}(10 \%)$ [74], induce PCa tumorigenesis via PI3K/mTOR [193]. Interestingly, YAP activates mTORC signaling in breast epithelial MCF10A cells. Mechanistically, YAP suppresses PTEN activity via miR-29 induction [194]. Consequently, in a transgene YAP mouse model, mTOR was activated, causing skin hyperplasia [194]. One of the strongest regulators of mTOR activity is amino-acid sensing; when amino-acid availability of specific amino acids is low, mTOR is switched off [189]. YAP/TAZ-TEAD induce the expression of a range of cellular amino-acid transporters [195,196], including the high-affinity hetero dimeric leucine transporter, LAT1 (encoded by SLC7A5 and SLC3A3). Expression of LAT1 results in increased uptake of leucine at nutrient-limiting conditions [195], as is prevalent in tumors. Consequently, the expression of amino-acid transporters activates mTOR [195-197]. These mechanisms thereby provide a metabolic advantage for tumor cells with hyperactive YAP/TAZ. Furthermore, integrin $\alpha 3$ controls YAP phosphorylation and nuclear localization via the focal adhesion kinase/cell division control protein 42/protein phosphatase 1A (FAK/Cdc42/PP1A) axis, which activates mTOR [198]. Although these studies were not carried out in the context of PCa, they did indicate that YAP/TAZ-TEAD activity might be triggering the activation of mTOR in PCa. Remarkably, PTEN is a negative regulator of YAP activity in the PCa PTEN/SMAD4 knockout mouse model [131]. It is, therefore, a relevant outstanding question as to whether there is a feedback loop between PTEN suppression and YAP activity in PCa. Additionally, it remains unclear whether resistance to hormone inhibition therapy occurs via positive selection of cells with high YAP activity, which in turn induce tumorigenesis synergistically via TEAD binding and PI3K/mTOR activation.

\subsection{Activator Protein (AP-1)}

The activator protein (AP-1) transcription factor consists of dimeric complexes, which include the DNA-binding protein families, cellular ju-nana (c-Jun), cellular FBJ osteosarcoma oncogene (c-Fos), activating transcription factor (ATF), and cellular musculoaponeurotic fibrosarcoma (c-MAF) proteins $[199,200]$. AP-1 activation is mediated via a range of paracrine signaling molecules, as well as by the mitogen-activated extracellular signaling responsive kinase kinases (MEKs) [199,201,202]. AP-1 regulates multiple cellular responses such as inflammation, proliferation, and apoptosis [200,203]. Importantly, genome-wide analysis revealed that YAP/TAZ-TEAD mediate tumorigenesis by co-occupying the same genomic region occupied by AP-1 [204,205]. YAP/TAZ-TEAD and the AP-1 interaction occurs with the aid of the p160 family of steroid receptor co-activators (SRC1-3) [206]. Interestingly, SRC-3 is overexpressed in PCa, which promotes cell proliferation via AR activation [207]. Treating LNCaP cells with DHT induces the activity of c-Jun and tumor necrosis factor alpha (TNF- $\alpha$ ) promoter activity, which contains AP-1 binding sites. In this context, the activation of AP-1 due to AR induction might synergistically be prompting YAP/TAZ target gene transcription [208]. These findings provide evidence for cross-talk between YAP/TAZ-TEAD and AP-1. Nonetheless, further investigation 
is required to understand the role of this signaling cross-talk in PCa development and its role in regulating AR.

\section{Conclusions and Perspectives}

To date, there are no identified somatic mutations of the Hippo pathway components in PCa. Furthermore, although YAP was identified to be amplified in a subset of PCa [209], it is evident that YAP/TAZ is a much more widespread contributor to PCa development. YAP and TAZ play key roles in multiple stages of PCa initiation, development, and progression, as well as regulation of AR signaling. However, the mechanistic insights into how YAP/TAZ becomes hyperactivated, how YAP/TAZ interacts with the stroma and their precise role in PCa development are currently far from fully elucidated. Obtaining further fundamental understanding of the complexity of YAP/TAZ hyperactivation in PCa onset and development is, therefore, crucial for improving future clinical interventions and care for PCa patients [210,211].

- How does YAP drive CRPC development? Androgen receptor bypass is a contributing mechanism via which PCa cells develop castration resistance [212]. Androgen-deprived PCa cells activate a variety of hormone receptors such as glucocorticoid receptor (GR) and its targets in order to overcome androgen dependence [212]. Importantly, GR signaling activates YAP in MDA-MB-231 breast cancer cells [213]. Additionally, the perplexing ability of tumors to activate steroidogenesis pathways causing AR hypersensitivity is not completely understood. Of note, YAP regulates steroidogenesis in ovarian granulosa cells [214]. Whether YAP is involved in inducing CRPC via AR bypass and intratumoral steroidogenesis, and whether YAP is essential for CRPC PCa cell survival are, to a great extent, still unexplored questions.

- The estrogen receptor (ER) plays an important role in $\mathrm{PCa}[215,216]$. ER $\alpha$ regulates proinflammatory and pro-proliferative targets and is associated with high Gleason score $[215,216]$. In comparison, ER $\beta$ receptor plays an anti-inflammatory, pro-apoptotic role $[215,216]$. Estradiol, the estrogen receptor agonist, activates the Hippo pathway in the breast SK-BR-3 cell line via G-protein-coupled estrogen receptor (GPER) [217]. Although anatomically distinct, the molecular and clinical similarities between breast and prostate cancer [217] highlight the importance of examining if a similar cross-talk mechanism is occurring in PCa.

- Activation of the Hippo kinase cascade module is a clear direction toward utilizing the Hippo pathway therapeutically $[161,181]$. However, an ongoing challenge of this route is the complexity of the Hippo pathway upstream regulators. Intriguingly, in PCa, it is unclear what causes the Hippo pathway dysregulation. Delineating the upstream regulators of the Hippo pathway in a PCa-specific context might, therefore, have direct clinical relevance. Importantly, YAP is upregulated in CRPC; therefore, developing YAP activity inhibitors is an equally important therapeutic direction. Successfully controlling YAP and/or TAZ activity state therapeutically would be an immense step toward developing a personalized therapeutic strategy in CRPC.

Author Contributions: Both authors wrote and commented on iterative drafts of the manuscript.

Funding: Work on-going in the Gram Hansen lab is supported by a University of Edinburgh Chancellor's Fellowship start-up fund, as well as by the Wellcome Trust University of Edinburgh Institutional Strategic Support Fund (ISSF3).

Acknowledgments: Lab members of the Gram Hansen lab, as well as Bin-Zhi Qian, are acknowledged for insightful and valuable discussions.

Conflicts of Interest: The authors declare no conflicts of interest. The funders had no role in the topics analyzed, in the writing of the manuscript, or in the decision to publish. 
Abbreviations

\begin{tabular}{|c|c|}
\hline ADT & Androgen deprivation therapy \\
\hline AMOT & Angiomotin \\
\hline AMPK & $5^{\prime}$ adenosine monophosphate-activated protein kinase \\
\hline AP-1 & Activator protein 1 \\
\hline $\mathrm{APC}$ & Adenomatous polyposis coli \\
\hline aPKC & Atypical protein kinase $C$ \\
\hline $\mathrm{AR}$ & Androgen receptor \\
\hline Arg/abl2 & Abelson-related gene \\
\hline ATF & Activating transcription factor \\
\hline CD133 & Cluster of differentiation 133 \\
\hline CD44 & Cluster of differentiation 44 \\
\hline Cdc42 & Cell division control protein 42 \\
\hline c-Fos & FBJ osteosarcoma oncogene \\
\hline cGMP & Cyclin guanosine monophosphate \\
\hline c-Jun & Cellular ju-nana \\
\hline c-MAF & Musculoaponeurotic fibrosarcoma \\
\hline c-MYC & Cellular myelocytomatosis \\
\hline CRPC & Castration-resistant prostate cancer \\
\hline CTGF & Connective tissue growth factor \\
\hline CXCL5 & $\mathrm{C}-\mathrm{X}-\mathrm{C}$ motif chemokine 5 \\
\hline CXCR2 & C-C chemokine receptor type 2 \\
\hline CYR61 & Cysteine-rich angiogenic factor \\
\hline DHT & Dihydrotestosterone \\
\hline DNMT3a & DNA methyltransferase 3 \\
\hline ECM & Extracellular matrix \\
\hline EMT & Epithelial-mesenchymal transition \\
\hline ER & Estrogen receptor \\
\hline ERG & ETS-regulated gene \\
\hline ETS & E26 transformation-specific transcription factors \\
\hline ETV1/4/5 & E26 transformation-specific variant $1 / 4 / 5$ \\
\hline EZH2 & Enhancer of zeste homolog 2 \\
\hline FAK & Focal Adhesion Kinase \\
\hline FDA & US food and drug administration \\
\hline FRDM6 & FERM domain-containing protein 6 \\
\hline GAP & Guanosine triphosphate (GTP)ase activating protein \\
\hline GTP & Guanosine triphosphate \\
\hline GR & Glucocorticoid receptor \\
\hline HMG-CoA & 3-hydroxy-3-methyl-glutaryl-coenzyme A \\
\hline Hsp27 & Heat shock protein 27 \\
\hline JMJD2A & Lysine-specific demethylase \\
\hline JNK & c-Jun N-terminal kinase \\
\hline KIBRA & Kidney- and brain-expressed protein \\
\hline LATS1/2 & Large tumor suppressor $1 / 2$ \\
\hline M2 & Tumor infiltration type II macrophages \\
\hline MAP4K & MAP kinase kinase kinase kinases \\
\hline MDSCs & Myeloid-derived suppressor cells \\
\hline miR302-367 & microRNA cluster 302-267 \\
\hline MOB1 & MOB kinase activator 1 \\
\hline MST1/2 & Mammalian Hippo homolog (Ste20-like kinases) \\
\hline mTOR & Mammalian target of rapamycin \\
\hline NF2/Merlin & Neurofibromatosis 2 \\
\hline NLK & Nemo-like kinase \\
\hline Par3 & Polarity protein 3 \\
\hline
\end{tabular}




$\begin{array}{ll}\text { PCa } & \text { Prostate cancer } \\ \text { PCSCs } & \text { Prostate cancer stem cells } \\ \text { PDE5 } & \text { Cyclic GMP-specific phosphodiesterase type 5 } \\ \text { PI3K-AKT } & \text { Phosphoinositide 3-kinase/protein kinase B } \\ \text { PKG } & \text { cGMP-dependent protein G } \\ \text { POZ } & \text { Pox virus and zinc finger protein } \\ \text { PPA1 } & \text { Protein phosphate 1 } \\ \text { PRC2 } & \text { Polycomb repressive complex 2 } \\ \text { PSA } & \text { Prostate-specific antigen } \\ \text { PTEN } & \text { Phosphatase and tensin homolog } \\ \text { RAC } & \text { Ras-related C3 botulinum toxin substrate 1 } \\ \text { RAF } & \text { Rapidly accelerated fibrosarcoma family of serine/threonine kinases } \\ \text { RhoGAP } & \text { Rho family of GTPases } \\ \text { SAV1 } & \text { Protein salvador homolog 1 } \\ \text { SH3BP1 } & \text { SH3 domain-binding protein 1 } \\ \text { Super TDU } & \text { VGLL4-mimicking peptide } \\ \text { TAZ } & \text { Transcriptional co-activator with PDZ-binding motif } \\ \text { TEAD1-4 } & \text { TEA domain family member 1-4 } \\ \text { VGLL4 } & \text { Vestigial-like 4 } \\ \text { WNT } & \text { Wingless } \\ \text { YAP } & \text { Yes-associated protein } \\ \text { 17-mer } & \text { YAP-like peptide }\end{array}$

\section{References}

1. Wong, M.C.S.; Goggins, W.B.; Wang, H.H.X.; Fung, F.D.H.; Leung, C.; Wong, S.Y.S.; Ng, C.F.; Sung, J.J.Y. Global Incidence and Mortality for Prostate Cancer: Analysis of Temporal Patterns and Trends in 36 Countries. Eur. Urol. 2016, 70, 862-874. [CrossRef] [PubMed]

2. Bray, F.; Ferlay, J.; Soerjomataram, I.; Siegel, R.L.; Torre, L.A.; Jemal, A. Global cancer statistics 2018: GLOBOCAN estimates of incidence and mortality worldwide for 36 cancers in 185 countries. CA Cancer J. Clin. 2018, 68, 394-424. [CrossRef] [PubMed]

3. Mcneal, J.; Kindrachuk, R.; Freiha, F.; Bostwick, D.; Redwine, E.; Stamey, T. Patterns of Progression in Prostate Cancer. Lancet 1986, 327, 60-63. [CrossRef]

4. Coleman, W.B. Molecular Pathogenesis of Prostate Cancer. In Molecular Pathology; Coleman, W., Tsongalis, G., Eds.; Elsevier: Berlin/Heidelberg, Germany, 2018; pp. 555-568, ISBN 9780128027615.

5. Shen, M.M.; Abate-Shen, C. Molecular genetics of prostate cancer: New prospects for old challenges. Genes Dev. 2010, 24, 1967-2000. [CrossRef]

6. De Reijke, T.M.; van Moorselaar, J.R. Ten-year Outcomes after Monitoring, Surgery, or Radiotherapy for Localized Prostate Cancer. Eur. Urol. 2017, 71, 491-492. [CrossRef] [PubMed]

7. Parker, C. Active surveillance: Towards a new paradigm in the management of early prostate cancer. Lancet Oncol. 2004, 5, 101-106. [CrossRef]

8. Huggins, C.; Hodges, C.V. Studies on Prostatic Cancer: I. The Effect of Castration, of Estrogen and of Androgen Injection on Serum Phosphatases in Metastatic Carcinoma of the Prostate. J. Urol. 1941, 168, 9-12.

9. Huggins, C. Endocrine-Induced Regression of Cancers. Cancer Res. 1967, 27, 1925-1930. [CrossRef]

10. Chen, Y.; Sawyers, C.L.; Scher, H.I. Targeting the androgen receptor pathway in prostate cancer. Curr. Opin. Pharmacol. 2008, 8, 440-448. [CrossRef] [PubMed]

11. Saad, F.; Chi, K.; Finelli, A.; Hotte, S.; Izawa, J.; Kapoor, A.; Kassouf, W.; Loblaw, A.; North, S.; Rendon, R.; et al. The 2015 CUA-CUOG Guidelines for the Management of Castration Resistant Prostate Cancer (CRPC). Can. Urol. Assoc. J. 2015, 9, 90. [CrossRef] [PubMed]

12. Mollica, V.; Di Nunno, V.; Cimadamore, A.; Lopez-Beltran, A.; Cheng, L.; Santoni, M.; Scarpelli, M.; Montironi, R.; Massari, F. Molecular Mechanisms Related to Hormone Inhibition Resistance in Prostate Cancer. Cells 2019, 8, 43. [CrossRef]

13. Vlachostergios, P.J.; Puca, L.; Beltran, H. Emerging Variants of Castration-Resistant Prostate Cancer. Curr. Oncol. Rep. 2017, 19, 1-17. [CrossRef] 
14. Chandrasekar, T.; Yang, J.; Gao, A.; Evans, C.P. Mechanisms of resistance in castration-resistant prostate cancer (CRPC). Transl. Androl. Urol. 2015, 4, 365-380. [PubMed]

15. Visakorpi, T.; Hyytinen, E.; Koivisto, P.; Tanner, M.; Keinänen, R.; Palmberg, C.; Palotie, A.; Tammela, T.; Isola, J.; Kallioniemi, O. In vivo amplification of the androgen receptor gene and progression of human prostate cancer. Nat. Genet. 1995, 9, 401-406. [CrossRef]

16. Gregory, C.W.; Johnson, R.T.; Mohler, J.L.; French, F.S.; Wilson, E.M. Androgen receptor stabilization in recurrent prostate cancer is associated with hypersensitivity to low androgen. Cancer Res. 2001, 61, 2892-2898.

17. Kim, K.; Wongvipat, J.; Watson, P.A.; Balbas, M.D.; Chen, Y.F.; Sawyers, C.L.; Viale, A.; Socci, N.D. Constitutively active androgen receptor splice variants expressed in castration-resistant prostate cancer require full-length androgen receptor. Proc. Natl. Acad. Sci. USA 2010, 107, 16759-16765.

18. Montgomery, R.B.; Mostaghel, E.A.; Vessella, R.; Hess, D.L.; Kalhorn, T.F.; Higano, C.S.; True, L.D.; Nelson, P.S. Maintenance of Intratumoral Androgens in Metastatic Prostate Cancer: A Mechanism for Castration-Resistant Tumor Growth. Cancer Res. 2008, 68, 4447-4454. [CrossRef]

19. Stanbrough, M.; Bubley, G.J.; Ross, K.; Golub, T.R.; Rubin, M.A.; Penning, T.M.; Febbo, P.G.; Balk, S.P. Increased Expression of Genes Converting Adrenal Androgens to Testosterone in Androgen-Independent Prostate Cancer. Cancer Res. 2006, 66, 2815-2825. [CrossRef]

20. Wang, Q.; Li, W.; Zhang, Y.; Yuan, X.; Xu, K.; Yu, J.; Chen, Z.; Beroukhim, R.; Wang, H.; Lupien, M.; et al. Androgen Receptor Regulates a Distinct Transcription Program in Androgen-Independent Prostate Cancer. Cell 2009, 138, 245-256. [CrossRef]

21. Moroishi, T.; Hansen, C.G.; Guan, K.-L. The emerging roles of YAP and TAZ in cancer. Nat. Rev. Cancer 2015, 15, 73-79. [CrossRef] [PubMed]

22. Moya, I.M.; Halder, G. Hippo-YAP/TAZ signalling in organ regeneration and regenerative medicine. Nat. Rev. Mol. Cell Biol. 2019, 20, 211-226. [CrossRef]

23. Dong, J.; Feldmann, G.; Huang, J.; Wu, S.; Zhang, N.; Comerford, S.A.; Gayyed, M.F.; Anders, R.A.; Maitra, A.; Pan, D. Elucidation of a Universal Size-Control Mechanism in Drosophila and Mammals. Cell 2007, 130, 1120-1133. [CrossRef]

24. Pan, D. The Hippo Signaling Pathway in Development and Cancer. Dev. Cell 2010, 19, 491-505. [CrossRef] [PubMed]

25. Park, J.H.; Shin, J.E.; Park, H.W. The Role of Hippo Pathway in Cancer Stem Cell Biology. Mol. Cells 2018, 41, 83-92.

26. Hansen, C.G.; Moroishi, T.; Guan, K.L. YAP and TAZ: A nexus for Hippo signaling and beyond. Trends Cell Biol. 2015, 25, 499-513. [CrossRef] [PubMed]

27. Santinon, G.; Pocaterra, A.; Dupont, S. Control of YAP/TAZ Activity by Metabolic and Nutrient-Sensing Pathways. Trends Cell Biol. 2016, 26, 289-299. [CrossRef] [PubMed]

28. Totaro, A.; Panciera, T.; Piccolo, S. YAP/TAZ upstream signals and downstream responses. Nat. Cell Biol. 2018, 20, 888-899. [CrossRef]

29. Yu, F.X.; Zhao, B.; Guan, K.L. Hippo Pathway in Organ Size Control, Tissue Homeostasis, and Cancer. Cell 2015, 163, 811-828. [CrossRef] [PubMed]

30. Chan, S.W.; Lim, C.J.; Chong, Y.F.; Pobbati, A.V; Huang, C.; Hong, W. Hippo Pathway-independent Restriction of TAZ and YAP by Angiomotin. J. Biol. Chem. 2011, 286, 7018-7026. [CrossRef] [PubMed]

31. Dupont, S.; Morsut, L.; Aragona, M.; Enzo, E.; Giulitti, S.; Cordenonsi, M.; Zanconato, F.; Le Digabel, J.; Forcato, M.; Bicciato, S.; et al. Role of YAP/TAZ in mechanotransduction. Nature 2011, 474, 179-184. [CrossRef] [PubMed]

32. Kofler, M.; Speight, P.; Little, D.; Di Ciano-Oliveira, C.; Szászi, K.; Kapus, A. Mediated nuclear import and export of TAZ and the underlying molecular requirements. Nat. Commun. 2018, 9, 4966. [CrossRef]

33. Zanconato, F.; Cordenonsi, M.; Piccolo, S. YAP/TAZ at the Roots of Cancer. Cancer Cell 2016, $29,783-803$. [CrossRef]

34. Steinhardt, A.A.; Gayyed, M.F.; Klein, A.P.; Dong, J.; Maitra, A.; Pan, D.; Montgomery, E.A.; Anders, R.A. Expression of Yes-associated protein in common solid tumors. Hum. Pathol. 2008, 39, 1582-1589. [CrossRef] [PubMed]

35. Schäfer, A.; Nousiainen, M.; Chan, E.H.Y.; Chalamalasetty, R.B.; Silljé, H.H.W.; Nigg, E.A. The Ste20-like kinase Mst2 activates the human large tumor suppressor kinase Lats1. Oncogene 2005, 24, 2076-2086. 
36. Hao, Y.; Chun, A.; Cheung, K.; Rashidi, B.; Yang, X. Tumor Suppressor LATS1 Is a Negative Regulator of Oncogene YAP. J. Biol. Chem. 2008, 283, 5496-5509. [CrossRef]

37. Pan, D.; Liu, B.; Wang, W.; Zheng, Y.; Uster, E.; Deng, H. Identification of Happyhour/MAP4K as Alternative Hpo/Mst-like Kinases in the Hippo Kinase Cascade. Dev. Cell 2015, 34, 642-655.

38. Oh, H.; Irvine, K.D. In vivo regulation of Yorkie phosphorylation and localization. Development 2008, 135, 1081-1088. [CrossRef] [PubMed]

39. Harvey, K.F.; Pfleger, C.M.; Hariharan, I.K. The Drosophila Mst Ortholog, hippo, Restricts Growth and Cell Proliferation and Promotes Apoptosis. Cell 2003, 114, 457-467. [CrossRef]

40. Jianhang, J.; Zhang, W.; Wang, B.; Richard, T.; Jiang, J. The Drosophila Ste20 family kinase dMST functions as a tumor suppressor by restricting cell proliferation and promoting apoptosis. Genes Dev. 2003, 17, 2514-2519.

41. Justice, R.W.; Zilian, O.; Woods, D.F.; Noll, M.; Bryant, P.J. The Drosophila Tumor-Suppressor Gene Warts Encodes a Homolog of Human Myotonic-Dystrophy Kinase and Is Required for the Control of Cell-Shape and Proliferation. Genes Dev. 1995, 9, 534-546. [CrossRef]

42. Li, Q.; Li, S.; Mana-Capelli, S.; Roth Flach, R.J.; Danai, L.V.; Amcheslavsky, A.; Nie, Y.; Kaneko, S.; Yao, X.; Chen, X.; et al. The Conserved Misshapen-Warts-Yorkie Pathway Acts in Enteroblasts to Regulate Intestinal Stem Cells in Drosophila. Dev. Cell 2014, 31, 291-304. [CrossRef]

43. Pantalacci, S.; Tapon, N.; Léopold, P. The Salvador partner Hippo promotes apoptosis and cell-cycle exit in Drosophila. Nat. Cell Biol. 2003, 5, 921-927.

44. Udan, R.S.; Kango-Singh, M.; Nolo, R.; Tao, C.; Halder, G. Hippo promotes proliferation arrest and apoptosis in the Salvador/Warts pathway. Nat. Cell Biol. 2003, 5, 914-920. [CrossRef]

45. Meng, Z.; Moroishi, T.; Mottier-Pavie, V.; Plouffe, S.W.; Hansen, C.G.; Hong, A.W.; Park, H.W.; Mo, J.-S.; Lu, W.; Lu, S.; et al. MAP4K family kinases act in parallel to MST1/2 to activate LATS1/2 in the Hippo pathway. Nat. Commun. 2015, 6, 8357. [CrossRef] [PubMed]

46. Zhao, B.; Wei, X.; Li, W.; Udan, R.S.; Yang, Q.; Kim, J.; Xie, J.; Ikenoue, T.; Yu, J.; Li, L.; et al. Inactivation of YAP oncoprotein by the Hippo pathway is involved in cell contact inhibition and tissue growth control. Genes Dev. 2007, 21, 2747-2761. [CrossRef] [PubMed]

47. Lei, Q.-Y.; Zhang, H.; Zhao, B.; Zha, Z.-Y.; Bai, F.; Pei, X.-H.; Zhao, S.; Xiong, Y.; Guan, K.-L. TAZ Promotes Cell Proliferation and Epithelial-Mesenchymal Transition and Is Inhibited by the Hippo Pathway. Mol. Cell. Biol. 2008, 28, 2426-2436. [CrossRef] [PubMed]

48. Zhao, B.; Li, L.; Tumaneng, K.; Wang, C.Y.; Guan, K.L. A coordinated phosphorylation by Lats and CK1 regulates YAP stability through SCF $\beta$-TRCP. Genes Dev. 2010, 24, 72-85. [CrossRef]

49. Liu, C.-Y.; Zha, Z.-Y.; Zhou, X.; Zhang, H.; Huang, W.; Zhao, D.; Li, T.; Chan, S.W.; Lim, C.J.; Hong, W.; et al. The Hippo Tumor Pathway Promotes TAZ Degradation by Phosphorylating a Phosphodegron and Recruiting the SCF $\beta$-TrCP E3 Ligase. J. Biol. Chem. 2010, 285, 37159-37169. [CrossRef] [PubMed]

50. Wang, S.; Xie, F.; Chu, F.; Zhang, Z.; Yang, B.; Dai, T.; Gao, L.; Wang, L.; Ling, L.; Jia, J.; et al. YAP antagonizes innate antiviral immunity and is targeted for lysosomal degradation through IKKI-mediated phosphorylation. Nat. Immunol. 2017, 18, 733-743. [CrossRef]

51. Schlegelmilch, K.; Mohseni, M.; Kirak, O.; Pruszak, J.; Rodriguez, J.R.; Zhou, D.; Kreger, B.T.; Vasioukhin, V.; Avruch, J.; Brummelkamp, T.R.; et al. Yap1 Acts Downstream of $\alpha$-Catenin to Control Epidermal Proliferation. Cell 2011, 144, 782-795. [CrossRef]

52. Ota, M.; Sasaki, H. Mammalian Tead proteins regulate cell proliferation and contact inhibition as transcriptional mediators of Hippo signaling. Development 2008, 135, 4059-4069. [CrossRef] [PubMed]

53. Zhang, H.; Liu, C.-Y.; Zha, Z.-Y.; Zhao, B.; Yao, J.; Zhao, S.; Xiong, Y.; Lei, Q.-Y.; Guan, K.-L. TEAD Transcription Factors Mediate the Function of TAZ in Cell Growth and Epithelial-Mesenchymal Transition. J. Biol. Chem. 2009, 284, 13355-13362. [CrossRef]

54. Zhao, B.; Ye, X.; Yu, J.; Li, L.; Li, W.; Li, S.; Yu, J.; Lin, J.D.; Wang, C.-Y.; Chinnaiyan, A.M.; et al. TEAD mediates YAP-dependent gene induction and growth control. Genes Dev. 2008, 22, 1962-1971. [CrossRef] [PubMed]

55. Vassilev, A.; Kaneko, K.J.; Shu, H.; Zhao, Y.; DePamphilis, M.L. TEAD/TEF transcription factors utilize the activation domain of YAP65, a Src/Yes-associated protein localized in the cytoplasm. Genes Dev. 2001, 15, 1229-1241. [CrossRef]

56. Zaidi, S.K.; Sullivan, A.J.; Medina, R.; Ito, Y.; van Wijnen, A.J.; Stein, J.L.; Lian, J.B.; Stein, G.S. Tyrosine phosphorylation controls Runx2-mediated subnuclear targeting of YAP to repress transcription. EMBO J. 2004, 23, 790-799. [CrossRef] 
57. Vlahov, N.; Scrace, S.; Soto, M.S.; Grawenda, A.M.; Bradley, L.; Pankova, D.; Papaspyropoulos, A.; Yee, K.S.; Buffa, F.; Goding, C.R.; et al. Alternate RASSF1 Transcripts Control SRC Activity, E-Cadherin Contacts, and YAP-Mediated Invasion. Curr. Biol. 2015, 25, 3019-3034. [CrossRef] [PubMed]

58. Byun, M.R.; Hwang, J.-H.; Kim, A.R.; Kim, K.M.; Park, J.I.; Oh, H.T.; Hwang, E.S.; Hong, J.-H. SRC activates TAZ for intestinal tumorigenesis and regeneration. Cancer Lett. 2017, 410, 32-40. [CrossRef] [PubMed]

59. Zhang, L.; Tang, F.; Terracciano, L.; Hynx, D.; Kohler, R.; Bichet, S.; Hess, D.; Cron, P.; Hemmings, B.A.; Hergovich, A.; et al. NDR Functions as a Physiological YAP1 Kinase in the Intestinal Epithelium. Curr. Biol. 2015, 25, 296-305. [CrossRef]

60. Tomlinson, V.; Gudmundsdottir, K.; Luong, P.; Leung, K.-Y.; Knebel, A.; Basu, S. JNK phosphorylates Yes-associated protein (YAP) to regulate apoptosis. Cell Death Dis. 2010, 1, e29. [CrossRef]

61. Codelia, V.A.; Sun, G.; Irvine, K.D. Regulation of YAP by Mechanical Strain through Jnk and Hippo Signaling. Curr. Biol. 2014, 24, 2012-2017. [CrossRef]

62. DeRan, M.; Yang, J.; Shen, C.-H.; Peters, E.C.; Fitamant, J.; Chan, P.; Hsieh, M.; Zhu, S.; Asara, J.M.; Zheng, B.; et al. Energy Stress Regulates Hippo-YAP Signaling Involving AMPK-Mediated Regulation of Angiomotin-like 1 Protein. Cell Rep. 2014, 9, 495-503. [CrossRef]

63. Wang, W.; Xiao, Z.-D.; Li, X.; Aziz, K.E.; Gan, B.; Johnson, R.L.; Chen, J. AMPK modulates Hippo pathway activity to regulate energy homeostasis. Nat. Cell Biol. 2015, 17, 490-499. [CrossRef]

64. Mo, J.; Meng, Z.; Kim, Y.C.; Park, H.W.; Hansen, C.G.; Kim, S. Cellular energy stress induces AMPK-mediated regulation of YAP and the Hippo pathway. Nat. Cell Biol. 2015, 17, 500-510. [CrossRef] [PubMed]

65. Moon, S.; Kim, W.; Kim, S.; Kim, Y.; Song, Y.; Bilousov, O.; Kim, J.; Lee, T.; Cha, B.; Kim, M.; et al. Phosphorylation by NLK inhibits YAP-14-3-3-interactions and induces its nuclear localization. EMBO Rep. 2017, 18, 61-71. [CrossRef]

66. Hong, A.W.; Meng, Z.; Yuan, H.; Plouffe, S.W.; Moon, S.; Kim, W.; Jho, E.; Guan, K. Osmotic stress-induced phosphorylation by NLK at Ser128 activates YAP. EMBO Rep. 2017, 18, 72-86. [CrossRef] [PubMed]

67. Mohamed, A.D.; Tremblay, A.M.; Murray, G.I.; Wackerhage, H. The Hippo signal transduction pathway in soft tissue sarcomas. Biochim. Biophys. Acta Rev. Cancer 2015, 1856, 121-129. [CrossRef]

68. Pinar, E.Z.; Filiz, K.C.; Seyma, O.; Ummuhan, D.; Esra, K. Increased expression of YAP1 in prostate cancer correlates with extraprostatic extension. Cancer Biol. Med. 2017, 14, 405.

69. Jiang, N.; Hjorth-Jensen, K.; Hekmat, O.; Iglesias-Gato, D.; Kruse, T.; Wang, C.; Wei, W.; Ke, B.; Yan, B.; Niu, Y.; et al. In vivo quantitative phosphoproteomic profiling identifies novel regulators of castration-resistant prostate cancer growth. Oncogene 2015, 34, 2764-2776. [CrossRef]

70. Sheng, X.; Li, W.B.; Wang, D.L.; Chen, K.H.; Cao, J.J.; Luo, Z.; He, J.; Li, M.C.; Liu, W.J.; Yu, C. YAP is closely correlated with castration-resistant prostate cancer, and downregulation of YAP reduces proliferation and induces apoptosis of PC-3 cells. Mol. Med. Rep. 2015, 12, 4867-4876. [CrossRef] [PubMed]

71. Zhang, L.; Yang, S.; Chen, X.; Stauffer, S.; Yu, F.; Lele, S.M.; Fu, K.; Datta, K.; Palermo, N.; Chen, Y.; et al. The Hippo Pathway Effector YAP Regulates Motility, Invasion, and Castration-Resistant Growth of Prostate Cancer Cells. Mol. Cell. Biol. 2015, 35, 1350-1362. [CrossRef] [PubMed]

72. Tomlins, S.A.; Laxman, B.; Varambally, S.; Cao, X.; Yu, J.; Helgeson, B.E.; Cao, Q.; Prensner, J.R.; Rubin, M.A.; Shah, R.B.; et al. Role of the TMPRSS2-ERG Gene Fusion in Prostate Cancer. Neoplasia 2008, 10, 177-188. [CrossRef] [PubMed]

73. Tomlins, S.A.; Rhodes, D.R.; Perner, S.; Dhanasekaran, S.M.; Mehra, R.; Sun, X.-W.; Varambally, S.; Cao, X.; Tchinda, J.; Kuefer, R.; et al. Recurrent Fusion of TMPRSS2 and ETS Transcription Factor Genes in Prostate Cancer. Science 2005, 310, 644-648. [CrossRef]

74. The Cancer Genome Atlas Research Network. The molecular taxonomy of primary prostate cancer. Cell 2015, 163, 1011-1025.

75. Nguyen, L.T.; Tretiakova, M.S.; Silvis, M.R.; Lucas, J.; Klezovitch, O.; Coleman, I.; Bolouri, H.; Kutyavin, V.I.; Morrissey, C.; True, L.D.; et al. ERG Activates the YAP1 Transcriptional Program and Induces the Development of Age-Related Prostate Tumors. Cancer Cell 2015, 27, 797-808. [CrossRef]

76. Korenchuk, S.; Lehr, J.E.; MClean, L.; Lee, Y.G.; Whitney, S.; Vessella, R.; Lin, D.L.; Pienta, K.J. VCaP, a cell-based model system of human prostate cancer. In Vivo 2001, 15, 163-168. [PubMed]

77. Kim, T.; Jin, F.; Shin, S.; Oh, S.; Lightfoot, S.A.; Grande, J.P.; Johnson, A.J.; van Deursen, J.M.; Wren, J.D.; Janknecht, R. Histone demethylase JMJD2A drives prostate tumorigenesis through transcription factor ETV1. J. Clin. Invest. 2016, 126, 706-720. [CrossRef] 
78. Maehama, T.; Dixon, J.E. The Tumor Suppressor, PTEN/MMAC1, Dephosphorylates the Lipid Second Messenger, Phosphatidylinositol 3,4,5-Trisphosphate. J. Biol. Chem. 1998, 273, 13375-13378. [CrossRef]

79. Jamaspishvili, T.; Berman, D.M.; Ross, A.E.; Scher, H.I.; De Marzo, A.M.; Squire, J.A.; Lotan, T.L. Clinical implications of PTEN loss in prostate cancer. Nat. Rev. Urol. 2018, 15, 222-234. [CrossRef] [PubMed]

80. Dongre, A.; Weinberg, R.A. New insights into the mechanisms of epithelial-mesenchymal transition and implications for cancer. Nat. Rev. Mol. Cell Biol. 2019, 20, 69-84. [CrossRef] [PubMed]

81. Vasioukhin, V.; Bauer, C.; Yin, M.; Fuchs, E. Directed actin polymerization is the driving force for epithelial cell- cell adhesion. Cell 2000, 100, 209-219. [CrossRef]

82. Schäfer, R.; Iden, S.; Collard, J.G.; Hirose, T.; Ohno, S.; Song, J.-Y.; van Riel, W.E. Tumor Type-Dependent Function of the Par3 Polarity Protein in Skin Tumorigenesis. Cancer Cell 2012, 22, 389-403.

83. Zhou, P.-J.; Wang, X.; An, N.; Wei, L.; Zhang, L.; Huang, X.; Zhu, H.H.; Fang, Y.-X.; Gao, W.-Q. Loss of Par3 promotes prostatic tumorigenesis by enhancing cell growth and changing cell division modes. Oncogene 2019, 38, 2192-2205. [CrossRef]

84. Zhou, P.-J.; Xue, W.; Peng, J.; Wang, Y.; Wei, L.; Yang, Z.; Zhu, H.H.; Fang, Y.-X.; Gao, W.-Q. Elevated expression of Par3 promotes prostate cancer metastasis by forming a Par3/aPKC/KIBRA complex and inactivating the hippo pathway. J. Exp. Clin. Cancer Res. 2017, 36, 139. [CrossRef]

85. Ikwegbue, P.; Masamba, P.; Oyinloye, B.; Kappo, A. Roles of Heat Shock Proteins in Apoptosis, Oxidative Stress, Human Inflammatory Diseases, and Cancer. Pharmaceuticals 2017, 11, 2. [CrossRef]

86. Zoubeidi, A.; Gleave, M. Small heat shock proteins in cancer therapy and prognosis. Int. J. Biochem. Cell Biol. 2012, 44, 1646-1656. [CrossRef] [PubMed]

87. Rocchi, P.; So, A.; Kojima, S.; Signaevsky, M.; Beraldi, E.; Fazli, L.; Hurtado-coll, A.; Yamanaka, K.; Gleave, M. Heat Shock Protein 27 Increases after Androgen Ablation and Plays a Cytoprotective Role in Hormone-Refractory Prostate Cancer. Cancer Res. 2004, 64, 6595-6602. [CrossRef]

88. Vahid, S.; Thaper, D.; Gibson, K.F.; Bishop, J.L.; Zoubeidi, A. Molecular chaperone Hsp27 regulates the Hippo tumor suppressor pathway in cancer. Sci. Rep. 2016, 6, 31842. [CrossRef] [PubMed]

89. Zhou, D.; Payer, B.; Bardeesy, N.; Avruch, J.; Yin, Y.; Lauwers, G.Y.; Xia, F.; Park, J.-S.; Conrad, C.; Lee, J.T.; et al. Mst1 and Mst2 Maintain Hepatocyte Quiescence and Suppress Hepatocellular Carcinoma Development through Inactivation of the Yap1 Oncogene. Cancer Cell 2009, 16, 425-438. [CrossRef] [PubMed]

90. Song, H.; Mak, K.K.; Topol, L.; Yun, K.; Hu, J.; Garrett, L.; Chen, Y.; Park, O.; Chang, J.; Simpson, R.M.; et al. Mammalian Mst1 and Mst2 kinases play essential roles in organ size control and tumor suppression. Proc. Natl. Acad. Sci. USA 2010, 107, 1431-1436. [CrossRef]

91. Loforese, G.; Malinka, T.; Keogh, A.; Baier, F.; Simillion, C.; Montani, M.; Halazonetis, T.D.; Candinas, D.; Stroka, D. Impaired liver regeneration in aged mice can be rescued by silencing Hippo core kinases MST1 and MST2. EMBO Mol. Med. 2017, 9, 46-60. [CrossRef] [PubMed]

92. Modi, P.K.; Faiena, I.; Kim, I.Y. Androgen Receptor. In Prostate Cancer; Mydlo, J.H., Godec, C.J., Eds.; Elsevier: Berlin/Heidelberg, Germany, 2016; pp. 21-28, ISBN 9780128000779.

93. Zhou, Y.; Bolton, E.C.; Jones, J.O. Androgens and androgen receptor signaling in prostate tumorigenesis. J. Mol. Endocrinol. 2015, 54, R15-R29. [CrossRef] [PubMed]

94. Gewirth, D.T.; Dollins, D.E.; Shaffer, P.L.; Jivan, A.; Claessens, F. Structural basis of androgen receptor binding to selective androgen response elements. Proc. Natl. Acad. Sci. USA 2004, 101, 4758-4763.

95. Zhang, B.; Kwon, O.-J.; Henry, G.; Malewska, A.; Wei, X.; Zhang, L.; Brinkley, W.; Zhang, Y.; Castro, P.D.; Titus, M.; et al. Non-Cell-Autonomous Regulation of Prostate Epithelial Homeostasis by Androgen Receptor. Mol. Cell 2016, 63, 976-989. [CrossRef] [PubMed]

96. Tan, M.E.; Li, J.; Xu, H.E.; Melcher, K.; Yong, E.L. Androgen receptor: Structure, role in prostate cancer and drug discovery. Acta Pharmacol. Sin. 2015, 36, 3-23. [CrossRef] [PubMed]

97. Gao, W.; Bohl, C.E.; Dalton, J.T. Chemistry and structural biology of androgen receptor. Chem. Rev. 2005, 105, 3352-3370. [CrossRef]

98. Kuser-Abali, G.; Alptekin, A.; Lewis, M.; Garraway, I.P.; Cinar, B. YAP1 and AR interactions contribute to the switch from androgen-dependent to castration-resistant growth in prostate cancer. Nat. Commun. 2015, 6, 1-13. [CrossRef]

99. Thalmann, N.; Edmund, E.; Hopwood, V.L.; Pathak, S.; Von Eschenbach, A.; Chung, L.K. Androgenindependent Cancer Progression and Bone Metastasis in the LNCaP Model of Human Prostate Cancer. Cancer Res. 1994, 2577-2582. 
100. Cinar, B.; Collak, F.K.; Lopez, D.; Mukhopadhyay, N.K.; Akgul, S.; Freeman, M.R.; Kilicarslan, M.; Gioeli, D.G. MST1 Is a Multifunctional Caspase-Independent Inhibitor of Androgenic Signaling. Cancer Res. 2011, 71 , 4303-4313. [CrossRef]

101. Kuser-Abali, G.; Alptekin, A.; Cinar, B. Overexpression of MYC and EZH2 cooperates to epigenetically silence MST1 expression. Epigenetics 2014, 9, 634-643. [CrossRef] [PubMed]

102. Dang, C.V.; O’Donnell, K.A.; Zeller, K.I.; Nguyen, T.; Osthus, R.C.; Li, F. The c-Myc target gene network. Semin. Cancer Biol. 2006, 16, 253-264. [CrossRef]

103. Gurel, B.; Iwata, T.; Koh, C.M.; Jenkins, R.B.; Lan, F.; Van Dang, C.; Hicks, J.L.; Morgan, J.; Cornish, T.C.; Sutcliffe, S.; et al. Nuclear MYC protein overexpression is an early alteration in human prostate carcinogenesis. Mod. Pathol. 2008, 21, 1156-1167. [CrossRef] [PubMed]

104. Koh, C.M.; Iwata, T.; Zheng, Q.; Bethel, C.; Yegnasubramanian, S.; De Marzo, A.M. Myc Enforces Overexpression of EZH2 in Early Prostatic Neoplasia via Transcriptional and Post-transcriptional Mechanisms. Oncotarget 2011, 2, 669-683. [CrossRef]

105. Cao, R.; Wang, L.; Wang, H.; Xia, L.; Erdjument-Bromage, H.; Tempst, P.; Jones, R.S.; Zhang, Y. Role of Histone H3 Lysine 27 Methylation in Polycomb-Group Silencing. Science 2002, 298, 1039-1043. [CrossRef]

106. Gan, L.; Yang, Y.; Li, Q.; Feng, Y.; Liu, T.; Guo, W. Epigenetic regulation of cancer progression by EZH2: From biological insights to therapeutic potential. Biomark. Res. 2018, 6, 1-10. [CrossRef]

107. Xu, K.; Wu, Z.J.; Groner, A.C.; He, H.H.; Cai, C.; Lis, R.T.; Wu, X.; Stack, E.C.; Loda, M.; Liu, T.; et al. EZH2 Oncogenic Activity in Castration-Resistant Prostate Cancer Cells Is Polycomb-Independent. Science 2012, 338, 1465-1469. [CrossRef]

108. Powzaniuk, M.; McElwee-Witmer, S.; Vogel, R.L.; Hayami, T.; Rutledge, S.J.; Chen, F.; Harada, S.; Schmidt, A.; Rodan, G.A.; Freedman, L.P.; et al. The LATS2/KPM Tumor Suppressor Is a Negative Regulator of the Androgen Receptor. Mol. Endocrinol. 2004, 18, 2011-2023. [CrossRef]

109. Stražišar, M.; Mlakar, V.; Glavač, D. LATS2 tumour specific mutations and down-regulation of the gene in non-small cell carcinoma. Lung Cancer 2009, 64, 257-262. [CrossRef]

110. Furth, N.; Pateras, I.S.; Rotkopf, R.; Vlachou, V.; Rivkin, I.; Schmitt, I.; Bakaev, D.; Gershoni, A.; Ainbinder, E.; Leshkowitz, D.; et al. LATS1 and LATS2 suppress breast cancer progression by maintaining cell identity and metabolic state. Life Sci. Alliance 2018, 1, e201800171. [CrossRef]

111. Moroishi, T.; Park, H.W.; Qin, B.; Chen, Q.; Meng, Z.; Plouffe, S.W.; Taniguchi, K.; Yu, F.-X.; Karin, M.; Pan, D.; et al. A YAP/TAZ-induced feedback mechanism regulates Hippo pathway homeostasis. Genes Dev. 2015, 29, 1271-1284. [CrossRef] [PubMed]

112. Feng, X.-H.; Li, L.; Yan, H.; Huang, J.; Ji, X.; Dai, X.; Liu, H.; Zhao, B.; Shen, S.; Guo, X. YAP activates the Hippo pathway in a negative feedback loop. Cell Res. 2017, 27, 1073.

113. He, C.; Lv, X.; Huang, C.; Hua, G.; Ma, B.; Chen, X.; Angeletti, P.C.; Dong, J.; Zhou, J.; Wang, Z.; et al. YAP1-LATS2 feedback loop dictates senescent or malignant cell fate to maintain tissue homeostasis. EMBO Rep. 2019, 20, e44948. [CrossRef]

114. Paszek, M.J.; Zahir, N.; Johnson, K.R.; Lakins, J.N.; Rozenberg, G.I.; Gefen, A.; Reinhart-King, C.A.; Margulies, S.S.; Dembo, M.; Boettiger, D.; et al. Tensional homeostasis and the malignant phenotype. Cancer Cell 2005, 8, 241-254. [CrossRef] [PubMed]

115. Calvo, F.; Ege, N.; Grande-Garcia, A.; Hooper, S.; Jenkins, R.P.; Chaudhry, S.I.; Harrington, K.; Williamson, P.; Moeendarbary, E.; Charras, G.; et al. Mechanotransduction and YAP-dependent matrix remodelling is required for the generation and maintenance of cancer-associated fibroblasts. Nat. Cell Biol. 2013, 15, 637-646. [CrossRef]

116. Wada, K.-I.; Itoga, K.; Okano, T.; Yonemura, S.; Sasaki, H. Hippo pathway regulation by cell morphology and stress fibers. Development 2011, 138, 3907-3914. [CrossRef]

117. Rausch, V.; Bostrom, J.R.; Park, J.; Bravo, I.R.; Feng, Y.; Hay, D.C.; Link, B.A.; Hansen, C.G. The Hippo Pathway Regulates Caveolae Expression and Mediates Flow Response via Caveolae. Curr. Biol. 2019, 29, 242-255e6. [CrossRef] [PubMed]

118. Nardone, G.; Oliver-De La Cruz, J.; Vrbsky, J.; Martini, C.; Pribyl, J.; Skládal, P.; Pešl, M.; Caluori, G.; Pagliari, S.; Martino, F.; et al. YAP regulates cell mechanics by controlling focal adhesion assembly. Nat. Commun. 2017, 8,15321 . [CrossRef] 
119. Mason, D.E.; Collins, J.M.; Dawahare, J.H.; Nguyen, T.D.; Lin, Y.; Voytik-Harbin, S.L.; Zorlutuna, P.; Yoder, M.C.; Boerckel, J.D. YAP and TAZ limit cytoskeletal and focal adhesion maturation to enable persistent cell motility. J. Cell Biol. 2019, 218, 1369-1389. [CrossRef] [PubMed]

120. Fletcher, G.C.; Elbediwy, A.; Khanal, I.; Ribeiro, P.S.; Tapon, N.; Thompson, B.J. The Spectrin cytoskeleton regulates the Hippo signalling pathway. EMBO J. 2015, 34, 940-954. [CrossRef]

121. Zhao, B.; Li, L.; Wang, L.; Wang, C.-Y.; Yu, J.; Guan, K.-L. Cell detachment activates the Hippo pathway via cytoskeleton reorganization to induce anoikis. Genes Dev. 2012, 26, 54-68. [CrossRef]

122. Deng, H.; Wang, W.; Yu, J.; Zheng, Y.; Qing, Y.; Pan, D. Spectrin regulates Hippo signaling by modulating cortical actomyosin activity. Elife 2015, 4, 1-17. [CrossRef]

123. Aragona, M.; Panciera, T.; Manfrin, A.; Giulitti, S.; Michielin, F.; Elvassore, N.; Dupont, S.; Piccolo, S. A Mechanical Checkpoint Controls Multicellular Growth through YAP/TAZ Regulation by Actin-Processing Factors. Cell 2013, 154, 1047-1059. [CrossRef]

124. Tang, Y.; Rowe, R.G.; Botvinick, E.L.; Kurup, A.; Putnam, A.J.; Seiki, M.; Weaver, V.M.; Keller, E.T.; Goldstein, S.; Dai, J.; et al. MT1-MMP-Dependent Control of Skeletal Stem Cell Commitment via a $\beta 1$-Integrin/YAP/TAZ Signaling Axis. Dev. Cell 2013, 25, 402-416. [CrossRef]

125. Shiao, S.L.; Chu, G.C.-Y.; Chung, L.W.K. Regulation of prostate cancer progression by the tumor microenvironment. Cancer Lett. 2016, 380, 340-348. [CrossRef] [PubMed]

126. Graham, N.; Qian, B.-Z. Mesenchymal Stromal Cells: Emerging Roles in Bone Metastasis. Int. J. Mol. Sci. 2018, 19, 1121. [CrossRef] [PubMed]

127. Varzavand, A.; Hacker, W.; Ma, D.; Gibson-Corley, K.; Hawayek, M.; Tayh, O.J.; Brown, J.A.; Henry, M.D.; Stipp, C.S. $\alpha 3 \beta 1$ Integrin Suppresses Prostate Cancer Metastasis via Regulation of the Hippo Pathway. Cancer Res. 2016, 76, 6577-6587. [CrossRef]

128. Secades, P.; van Hulst, L.; Sonnenberg, A.; Song, J.-Y.; Kreft, M.; Sachs, N. Loss of integrin $\alpha 3$ prevents skin tumor formation by promoting epidermal turnover and depletion of slow-cycling cells. Proc. Natl. Acad. Sci. USA 2012, 109, 21468-21473.

129. Pickup, M.W.; Mouw, J.K.; Weaver, V.M. The extracellular matrix modulates the hallmarks of cancer. EMBO Rep. 2014, 15, 1243-1253. [CrossRef]

130. Kerkar, S.P.; Restifo, N.P. Cellular Constituents of Immune Escape within the Tumor Microenvironment. Cancer Res. 2012, 72, 3125-3130. [CrossRef]

131. Wang, G.; Lu, X.; Dey, P.; Deng, P.; Wu, C.C.; Jiang, S.; Fang, Z.; Zhao, K.; Konaparthi, R.; Hua, S.; et al. Targeting YAP-Dependent MDSC Infiltration Impairs Tumor Progression. Cancer Discov. 2016, 6, 80-95. [CrossRef] [PubMed]

132. Talmadge, J.E.; Gabrilovich, D.I. History of myeloid-derived suppressor cells. Nat. Rev. Cancer 2013, 13, 739-752. [CrossRef] [PubMed]

133. Surana, R.; Yi, C.; Weiner, L.M.; Graham, G.T.; Shahbazian, D.; White, S.M.; Chen, H.; Zhang, W.; Murakami, S. Yes-associated protein mediates immune reprogramming in pancreatic ductal adenocarcinoma. Oncogene 2016, 36, 1232-1244.

134. Guo, X.; Zhao, Y.; Yan, H.; Yang, Y.; Shen, S.; Dai, X.; Ji, X.; Ji, F.; Gong, X.; Li, L.; et al. Single tumor-initiating cells evade immune clearance by recruiting type II macrophages. Genes Dev. 2017, 31, 247-259. [CrossRef]

135. Chan, S.W.; Lim, C.J.; Guo, K.; Ng, C.P.; Lee, I.; Hunziker, W.; Zeng, Q.; Hong, W. A Role for TAZ in Migration, Invasion, and Tumorigenesis of Breast Cancer Cells. Cancer Res. 2008, 68, 2592-2598. [CrossRef] [PubMed]

136. Cordenonsi, M.; Zanconato, F.; Azzolin, L.; Forcato, M.; Rosato, A.; Frasson, C.; Inui, M.; Montagner, M.; Parenti, A.R.; Poletti, A.; et al. The Hippo Transducer TAZ Confers Cancer Stem Cell-Related Traits on Breast Cancer Cells. Cell 2011, 147, 759-772. [CrossRef] [PubMed]

137. Bhat, K.P.L.; Salazar, K.L.; Balasubramaniyan, V.; Wani, K.; Heathcock, L.; Hollingsworth, F.; James, J.D.; Gumin, J.; Diefes, K.L.; Kim, S.H.; et al. The transcriptional coactivator TAZ regulates mesenchymal differentiation in malignant glioma. Genes Dev. 2011, 25, 2594-2609. [CrossRef]

138. Zanconato, F.; Battilana, G.; Forcato, M.; Filippi, L.; Azzolin, L.; Manfrin, A.; Quaranta, E.; Di Biagio, D.; Sigismondo, G.; Guzzardo, V.; et al. Transcriptional addiction in cancer cells is mediated by YAP/TAZ through BRD4. Nat. Med. 2018, 24, 1599-1610. [CrossRef] [PubMed]

139. Park, H.W.; Kim, Y.C.; Yu, B.; Moroishi, T.; Mo, J.S.; Plouffe, S.W.; Meng, Z.; Lin, K.C.; Yu, F.X.; Alexander, C.M.; et al. Alternative Wnt Signaling Activates YAP/TAZ. Cell 2015, 162, 780-794. [CrossRef] 
140. Hong, J.-H.; Hwang, E.S.; Michael, T.M.; Amsterdam, A.; Tian, Y.; Kalmukova, R.; Mueller, E.; Benjamin, T.; Spiegelman, B.M.; Sharp, P.A.; et al. TAZ, a Transcriptional Modulator of Mesenchymal Stem Cell Differentiation. Science 2005, 309, 1074-1078. [CrossRef] [PubMed]

141. Liu, C.Y.; Yu, T.; Huang, Y.; Cui, L.; Hong, W. ETS (E26 transformation-specific) up-regulation of the transcriptional co-Activator TAZ promotes cell migration and metastasis in prostate cancer. J. Biol. Chem. 2017, 292, 9420-9430. [CrossRef]

142. Parrini, M.C.; Sadou-Dubourgnoux, A.; Aoki, K.; Kunida, K.; Biondini, M.; Hatzoglou, A.; Poullet, P.; Formstecher, E.; Yeaman, C.; Matsuda, M.; et al. SH3BP1, an Exocyst-Associated RhoGAP, Inactivates Rac1 at the Front to Drive Cell Motility. Mol. Cell 2011, 42, 650-661. [CrossRef]

143. Seo, W.I.; Park, S.; Gwak, J.; Ju, B.G.; Chung, J.I.; Kang, P.M.; Oh, S. Wnt signaling promotes androgen-independent prostate cancer cell proliferation through up-regulation of the hippo pathway effector YAP. Biochem. Biophys. Res. Commun. 2017, 486, 1034-1039. [CrossRef]

144. Yuan, X.; Cai, C.; Chen, S.; Chen, S.; Yu, Z.; Balk, S.P. Androgen receptor functions in castration-resistant prostate cancer and mechanisms of resistance to new agents targeting the androgen axis. Oncogene 2014, 33, 2815-2825. [CrossRef]

145. Wang, G.; Wang, Z.; Sarkar, F.H.; Wei, W. Targeting Prostate Cancer Stem Cells for Cancer Therapy. Discov. Med. 2012, 13, 135-142. [PubMed]

146. Collins, A.T.; Habib, F.K.; Maitland, N.J.; Neal, D.E. Identification and isolation of human prostate epithelial stem cells based on $\alpha 2 \beta 1$-integrin expression. J. Cell Sci. 2001, 114, 3865-3872. [PubMed]

147. Richardson, G.D.; Robson, C.N.; Lang, S.H.; Neal, D.E.; Maitland, N.J.; Collins, A.T. CD133, a novel marker for human prostatic epithelial stem cells. J. Cell Sci. 2004, 117, 3539-3545. [CrossRef]

148. Garraway, I.P.; Sun, W.; Tran, C.P.; Perner, S.; Zhang, B.; Goldstein, A.S.; Hahm, S.A.; Haider, M.; Head, C.S.; Reiter, R.E.; et al. Human prostate sphere-forming cells represent a subset of basal epithelial cells capable of glandular regeneration in vivo. Prostate 2009, 70, 491-501. [CrossRef] [PubMed]

149. Qin, W.; Zheng, Y.; Qian, B.-Z.; Zhao, M. Prostate Cancer Stem Cells and Nanotechnology: A Focus on Wnt Signaling. Front. Pharmacol. 2017, 8, 1-12. [CrossRef] [PubMed]

150. Mansukhani, A.; Coarfa, C.; Gunaratne, P.H.; Basilico, C.; Basu-Roy, U.; Lim, D.-S.; Seo, E. SOX2 Regulates YAP1 to Maintain Stemness and Determine Cell Fate in the Osteo-Adipo Lineage. Cell Rep. 2013, 3, 2075-2087.

151. Song, S.; Ajani, J.A.; Honjo, S.; Maru, D.M.; Chen, Q.; Scott, A.W.; Heallen, T.R.; Xiao, L.; Hofstetter, W.L.; Weston, B.; et al. Hippo coactivator YAP1 upregulates SOX9 and endows esophageal Cancer cells with stem-like properties. Cancer Res. 2014, 74, 4170-4182. [CrossRef]

152. Lai, C.-J.; Lin, C.-Y.; Liao, W.-Y.; Hour, T.-C.; Wang, H.-D.; Chuu, C.-P. CD44 Promotes Migration and Invasion of Docetaxel-Resistant Prostate Cancer Cells Likely via Induction of Hippo-Yap Signaling. Cells 2019, 8, 295. [CrossRef]

153. Guo, Y.; Cui, J.; Ji, Z.; Cheng, C.; Zhang, K.; Zhang, C.; Chu, M.; Zhao, Q.; Yu, Z.; Zhang, Y.; et al. miR-302/367/LATS2/YAP pathway is essential for prostate tumor-propagating cells and promotes the development of castration resistance. Oncogene 2017, 36, 6336-6347. [CrossRef] [PubMed]

154. Liu, N.; Mei, L.; Fan, X.; Tang, C.; Ji, X.; Hu, X.; Shi, W.; Qian, Y.; Hussain, M.; Wu, J.; et al. Phosphodiesterase 5/protein kinase $\mathrm{G}$ signal governs stemness of prostate cancer stem cells through Hippo pathway. Cancer Lett. 2016, 378, 38-50. [CrossRef] [PubMed]

155. Jiang, N.; Ke, B.; Hjort-Jensen, K.; Iglesias-Gato, D.; Wang, Z.; Chang, P.; Zhao, Y.; Niu, X.; Wu, T.; Peng, B.; et al. YAP1 regulates prostate cancer stem cell-like characteristics to promote castration resistant growth. Oncotarget 2017, 8, 115054-115067. [CrossRef] [PubMed]

156. Schmelzle, T.; Roma, G.; Ruchti, A.; Schübeler, D.; Clay, I.; Bardet, A.F.; Stein, C.; Bauer, A.; Bouwmeester, T.; Agarinis, C.; et al. YAP1 Exerts Its Transcriptional Control via TEAD-Mediated Activation of Enhancers. PLOS Genet. 2015, 11, e1005465.

157. Li, Z.; Zhao, B.; Wang, P.; Chen, F.; Dong, Z.; Yang, H. Structural insights into the YAP and TEAD complex service Structural insights into the YAP and TEAD complex. Cell 2010, 3, 8-187.

158. Holden, J.K.; Cunningham, C.N. Targeting the Hippo Pathway and Cancer through the TEAD Family of Transcription Factors. Cancers 2018, 10, 81. [CrossRef]

159. Liu-Chittenden, Y.; Huang, B.; Shim, J.S.; Chen, Q.; Lee, S.-J.; Anders, R.A.; Liu, J.O.; Pan, D. Genetic and pharmacological disruption of the TEAD-YAP complex suppresses the oncogenic activity of YAP. Genes Dev. 2012, 26, 1300-1305. [CrossRef] 
160. Feng, W.; Dasari, V.R.; Gogoi, R.; Carey, D.J.; Nash, J.; Mazack, V. Verteporfin exhibits YAP-independent anti-proliferative and cytotoxic effects in endometrial cancer cells. Oncotarget 2017, 8, 28628-28640.

161. Lin, K.C.; Park, H.W.; Guan, K.-L. Deregulation and Therapeutic Potential of The Hippo Pathway in Cancer. Annu. Rev. Cancer Biol 2018, 2, 59-79. [CrossRef]

162. Zhang, L.; Li, P.; Ji, H.; Zhao, Y.; Yin, M.-X.; Lu, Y.; Wang, H.; Zhou, Z.; Zhang, W.; Lv, D.; et al. A novel partner of Scalloped regulates Hippo signaling via antagonizing Scalloped-Yorkie activity. Cell Res. 2013, 23, 1201-1214.

163. Zhang, W.; Gao, Y.; Li, P.; Shi, Z.; Guo, T.; Li, F.; Han, X.; Feng, Y.; Zheng, C.; Wang, Z.; et al. VGLL4 functions as a new tumor suppressor in lung cancer by negatively regulating the YAP-TEAD transcriptional complex. Cell Res. 2014, 24, 331-343. [CrossRef]

164. Jiao, S.; Wang, H.; Shi, Z.; Dong, A.; Zhang, W.; Song, X.; He, F.; Wang, Y.; Zhang, Z.; Wang, W.; et al. A Peptide Mimicking VGLL4 Function Acts as a YAP Antagonist Therapy against Gastric Cancer. Cancer Cell 2014, 25, 166-180. [CrossRef]

165. Zhang, Z.; Lin, Z.; Zhou, Z.; Shen, H.C.; Yan, S.F.; Mayweg, A.V.; Xu, Z.; Qin, N.; Wong, J.C.; Zhang, Z.; et al. Structure-Based Design and Synthesis of Potent Cyclic Peptides Inhibiting the YAP-TEAD Protein-Protein Interaction. ACS Med. Chem. Lett. 2014, 5, 993-998. [CrossRef]

166. Zhou, Z.; Hu, T.; Xu, Z.; Lin, Z.; Zhang, Z.; Feng, T.; Zhu, L.; Rong, Y.; Shen, H.; Luk, J.M.; et al. Targeting Hippo pathway by specific interruption of YAP-TEAD interaction using cyclic YAP-like peptides. FASEB J. 2015, 29, 724-732. [CrossRef] [PubMed]

167. Gronich, N.; Rennert, G. Beyond aspirin - Cancer prevention with statins, metformin and bisphosphonates. Nat. Rev. Clin. Oncol. 2013, 10, 625-642. [CrossRef] [PubMed]

168. Stancu, C.; Sima, A. Statins: Mechanism of action and effects. J. Cell. Mol. Med. 2001, 5, 378-387. [CrossRef] [PubMed]

169. Sorrentino, G.; Ruggeri, N.; Specchia, V.; Cordenonsi, M.; Mano, M.; Dupont, S.; Manfrin, A.; Ingallina, E.; Sommaggio, R.; Piazza, S.; et al. Metabolic control of YAP and TAZ by the mevalonate pathway. Nat. Cell Biol. 2014, 16, 357-366. [CrossRef]

170. Wang, Z.; Wu, Y.; Wang, H.; Zhang, Y.; Mei, L.; Fang, X.; Zhang, X.; Zhang, F.; Chen, H.; Liu, Y.; et al. Interplay of mevalonate and Hippo pathways regulates RHAMM transcription via YAP to modulate breast cancer cell motility. Proc. Natl. Acad. Sci. USA 2014, 111, E89-E98. [CrossRef]

171. Babcook, M.A.; Sramkoski, R.M.; Fujioka, H.; Daneshgari, F.; Almasan, A.; Shukla, S.; Nanavaty, R.R.; Gupta, S. Combination simvastatin and metformin induces G1-phase cell cycle arrest and Ripk1- and Ripk3-dependent necrosis in C4-2B osseous metastatic castration-resistant prostate cancer cells. Cell Death Dis. 2014, 5, e1536. [CrossRef]

172. Ho, W.; Choo, D.-W.; Wu, Y.-J.; Chan, T.-F.; Lin, Z.-F. Statins Use and the Risk of Prostate Cancer in Ischemic Heart Disease Patients in Taiwan. Clin. Pharmacol. Ther. 2019. [CrossRef]

173. Van Rompay, M.I.; Solomon, K.R.; Nickel, J.C.; Ranganathan, G.; Kantoff, P.W.; McKinlay, J.B. Prostate cancer incidence and mortality among men using statins and non-statin lipid-lowering medications. Eur. J. Cancer 2019, 1-9. [CrossRef]

174. O'Neill, E.; Rushworth, L.; Baccarini, M.; Kolch, W. Role of the Kinase MST2 in Suppression of Apoptosis by the Proto-Oncogene Product Raf-1. Science 2004, 306, 2267-2270. [CrossRef] [PubMed]

175. Monia, B.P.; Sasmor, H.; Johnston, J.F.; Freier, S.M.; Lesnik, E.A.; Muller, M.; Geiger, T.; Altmann, K.-H.; Moser, H.; Fabbro, D. Sequence-specific antitumor activity of a phosphorothioate oligodeoxyribonucleotide targeted to human C- raf kinase supports an antisense mechanism of action in vivo. Proc. Natl. Acad. Sci. USA 1996, 93, 15481-15484. [CrossRef]

176. Khazak, V.; Astsaturov, I.; Serebriiskii, I.G.; Golemis, E.A. Selective Raf inhibition in cancer therapy. Expert Opin. Ther. Targets 2007, 11, 1587-1609. [CrossRef] [PubMed]

177. Cripps, M.C.; Figueredo, A.T.; Amit, M.O.; Taylor, M.J.; Fields, A.L.; Holmlund, J.T.; McIntosh, L.W.; Geary, R.S.; Eisenhauer, E.A. Phase II randomized study of ISIS 3521 and ISIS 5132 in patients with locally advanced or metastatic colorectal cancer: A National Cancer Institute of Canada clinical trials group study. Clin. Cancer Res. 2002, 8, 2188-2192. [PubMed]

178. Oza, A.M.; Elit, L.; Swenerton, K.; Faught, W.; Ghatage, P.; Carey, M.; McIntosh, L.; Dorr, A.; Holmlund, J.T.; Eisenhauer, E. Phase II study of CGP 69846A (ISIS 5132) in recurrent epithelial ovarian cancer: An NCIC clinical trials group study (NCIC IND.116). Gynecol. Oncol. 2003, 89, 129-133. [CrossRef] 
179. Tolcher, A.W.; Reyno, L.; Venner, P.M.; Ernst, S.D.; Moore, M.; Geary, R.S.; Chi, K.; Hall, S.; Walsh, W.; Eisenhauer, E. A randomized Phase II and pharmacokinetic study of the antisense oligonucleotides ISIS 3521 and ISIS 5132 in patients with hormone-refractory prostate cancer. Clin. Cancer Res. 2002, 8, 2530-2535.

180. Murray, B.; Hayward, M.M.; Kurumbail, R.G. CHAPTER 14. The Future of Kinase Therapeutics. In Kinase Drug Discovery: Modern Approchase; The Royal Society of Chemistry: London, UK, 2018; pp. 381-405, ISBN 9781788013093.

181. Ferguson, F.M.; Gray, N.S. Kinase inhibitors: The road ahead. Nat. Rev. Drug Discov. 2018, 17, $353-376$. [CrossRef] [PubMed]

182. Azzolin, L.; Panciera, T.; Soligo, S.; Enzo, E.; Bicciato, S.; Dupont, S.; Bresolin, S.; Frasson, C.; Basso, G.; Guzzardo, V.; et al. YAP/TAZ Incorporation in the $\beta$-Catenin Destruction Complex Orchestrates the Wnt Response. Cell 2014, 158, 157-170. [CrossRef] [PubMed]

183. Azzolin, L.; Zanconato, F.; Bresolin, S.; Forcato, M.; Basso, G.; Bicciato, S.; Cordenonsi, M.; Piccolo, S. Role of TAZ as mediator of wnt signaling. Cell 2012, 151, 1443-1456. [CrossRef]

184. Cai, J.; Maitra, A.; Anders, R.A.; Taketo, M.M.; Pan, D. $\beta$-catenin destruction complex-independent regulation of Hippo-YAP signaling by APC in intestinal tumorigenesis. Genes Dev. 2015, 29, 1493-1506. [CrossRef]

185. Yardy, G.W.; Brewster, S.F. Wnt signalling and prostate cancer. Prostate Cancer Prostatic Dis. 2005, 8, 119-126. [CrossRef]

186. Bruxvoort, K.J.; Charbonneau, H.M.; Giambernardi, T.A.; Goolsby, J.C.; Qian, C.-N.; Zylstra, C.R.; Robinson, D.R.; Roy-Burman, P.; Shaw, A.K.; Buckner-Berghuis, B.D.; et al. Inactivation of Apc in the Mouse Prostate Causes Prostate Carcinoma. Cancer Res. 2007, 67, 2490-2496. [CrossRef]

187. Yu, F.; Zhao, B.; Panupinthu, N.; Jewell, J.L.; Lian, I.; Wang, L.H.; Zhao, J.; Tumaneng, K.; Li, H.; Fu, X.; et al. Regulation Of The Hippo-YAP Pathway By G-Protein- Coupled Receptor Signaling. Cell 2012, 150, 1-11. [CrossRef]

188. Rabanal-Ruiz, Y.; Korolchuk, V.I. mTORC1 and Nutrient Homeostasis: The Central Role of the Lysosome. Int. J. Mol. Sci. 2018, 19, 818. [CrossRef] [PubMed]

189. Kim, J.; Guan, K.-L. mTOR as a central hub of nutrient signalling and cell growth. Nat. Cell Biol. 2019, 21, 63-71. [CrossRef]

190. Carver, B.S.; Chapinski, C.; Wongvipat, J.; Hieronymus, H.; Chen, Y.; Chandarlapaty, S.; Arora, V.K.; Le, C.; Koutcher, J.; Scher, H.; et al. Reciprocal Feedback Regulation of PI3K and Androgen Receptor Signaling in PTEN-Deficient Prostate Cancer. Cancer Cell 2011, 19, 575-586. [CrossRef] [PubMed]

191. Mulholland, D.J.; Tran, L.M.; Li, Y.; Cai, H.; Morim, A.; Wang, S.; Plaisier, S.; Garraway, I.P.; Huang, J.; Graeber, T.G.; et al. Cell autonomous role of PTEN in regulating castration-resistant prostate cancer growth. Cancer Cell 2011, 19, 792-804. [CrossRef]

192. Crumbaker, M.; Khoja, L.; Joshua, A.M. AR signaling and the PI3K pathway in prostate cancer. Cancers 2017, 9, 34. [CrossRef]

193. Blattner, M.; Liu, D.; Robinson, B.D.; Huang, D.; Poliakov, A.; Gao, D.; Nataraj, S.; Deonarine, L.D.; Augello, M.A.; Sailer, V.; et al. SPOP Mutation Drives Prostate Tumorigenesis In Vivo through Coordinate Regulation of PI3K/mTOR and AR Signaling. Cancer Cell 2017, 31, 436-451. [CrossRef] [PubMed]

194. Tumaneng, K.; Schlegelmilch, K.; Russell, R.C.; Yimlamai, D.; Basnet, H.; Mahadevan, N.; Fitamant, J.; Bardeesy, N.; Camargo, F.D.; Guan, K.L. YAP mediates crosstalk between the Hippo and PI(3)K-TOR pathways by suppressing PTEN via miR-29. Nat. Cell Biol. 2012, 14, 1322-1329. [CrossRef] [PubMed]

195. Hansen, C.G.; Ng, Y.L.D.; Lam, W.-L.M.; Plouffe, S.W.; Guan, K.-L. The Hippo pathway effectors YAP and TAZ promote cell growth by modulating amino acid signaling to mTORC1. Cell Res. 2015, 25, 1299-1313. [CrossRef]

196. Park, Y.-Y.; Lee, J.-S.; Rupaimoole, R.; Jang, H.-J.; Mills, G.B.; Park, Y.N.; Jeong, W.; Rodriguez-Aguayo, C.; Sood, A.K.; Yoo, J.E.; et al. Yes-associated protein 1 and transcriptional coactivator with PDZ-binding motif activate the mammalian target of rapamycin complex 1 pathway by regulating amino acid transporters in hepatocellular carcinoma. Hepatology 2015, 63, 159-172. [CrossRef] [PubMed]

197. Nicklin, P.; Bergman, P.; Zhang, B.; Triantafellow, E.; Wang, H.; Nyfeler, B.; Yang, H.; Hild, M.; Kung, C.; Wilson, C.; et al. Bidirectional Transport of Amino Acids Regulates mTOR and Autophagy. Cell 2009, 136, 521-534. [CrossRef] [PubMed]

198. Hu, J.K.H.; Du, W.; Shelton, S.J.; Oldham, M.C.; DiPersio, C.M.; Klein, O.D. An FAK-YAP-mTOR Signaling Axis Regulates Stem Cell-Based Tissue Renewal in Mice. Cell Stem Cell 2017, 21, 91-106.e6. [CrossRef] 
199. Whitmarsh, A.J.; Davis, R.J. Transcription factor AP-1 regulation by mitogen-activated protein kinase signal transduction pathways. J. Mol. Med. 1996, 74, 589-607. [CrossRef]

200. Eferl, R.; Wagner, E.F. AP-1: A double-edged sword in tumorigenesis. Nat. Rev. Cancer 2003, 3, 859-868. [CrossRef]

201. Rössler, O.G.; Henß, I.; Thiel, G. Transcriptional response to muscarinic acetylcholine receptor stimulation: Regulation of Egr-1 biosynthesis by ERK, Elk-1, MKP-1, and calcineurin in carbachol-stimulated human neuroblastoma cells. Arch. Biochem. Biophys. 2008, 470, 93-102. [CrossRef] [PubMed]

202. Thiel, G.; Rössler, O.G. Immediate-Early Transcriptional Response to Angiotensin II in Human Adrenocortical Cells. Endocrinology 2011, 152, 4211-4223. [CrossRef] [PubMed]

203. Kim, J.; Woolridge, S.; Biffi, R.; Borghi, E.; Lassak, A.; Ferrante, P.; Amini, S.; Khalili, K.; Safak, M. Members of the AP-1 Family, c-Jun and c-Fos, Functionally Interact with JC Virus Early Regulatory Protein Large T Antigen. J. Virol. 2003, 77, 5241-5252. [CrossRef]

204. Zanconato, F.; Forcato, M.; Battilana, G.; Azzolin, L.; Quaranta, E.; Bodega, B.; Rosato, A.; Bicciato, S.; Cordenonsi, M.; Piccolo, S. Genome-wide association between YAP/TAZ/TEAD and AP-1 at enhancers drives oncogenic growth. Nat. Cell Biol. 2015, 17, 1218-1227. [CrossRef] [PubMed]

205. Maglic, D.; Schlegelmilch, K.; Dost, A.F.; Panero, R.; Dill, M.T.; Calogero, R.A.; Camargo, F.D. YAP-TEAD signaling promotes basal cell carcinoma development via a c-JUN/AP1 axis. EMBO J. 2018, 37, e98642. [CrossRef]

206. Zhu, L.J.; Mercurio, A.M.; Li, H.; Cotton, J.L.; Ou, J.; Mao, J.; Liu, X.; Davis, R.J.; Li, Q.; Park, J.-S.; et al. Tead and AP1 Coordinate Transcription and Motility. Cell Rep. 2016, 14, 1169-1180.

207. Lin, S.-H.; Zhou, H.-J.; Tsai, M.-J.; Ittmann, M.; Erdem, H.; Ayala, G.; Yan, J.; Tsai, S.Y.; Luo, W. SRC-3 Is Required for Prostate Cancer Cell Proliferation and Survival. Cancer Res. 2017, 65, 7976-7983.

208. Thiel, G.; Welck, J.; Wissenbach, U.; Rössler, O.G. Dihydrotestosterone activates AP-1 in LNCaP prostate cancer cells. Int. J. Biochem. Cell Biol. 2019, 110, 9-20. [CrossRef]

209. Wanjala, J.; Taylor, B.S.; Chapinski, C.; Hieronymus, H.; Wongvipat, J.; Chen, Y.; Nanjangud, G.J.; Schultz, N.; Xie, Y.; Liu, S.; et al. Identifying Actionable Targets through Integrative Analyses of GEM Model and Human Prostate Cancer Genomic Profiling. Mol. Cancer Ther. 2015, 14, 278-288. [CrossRef] [PubMed]

210. Koo, K.M.; Mainwaring, P.N.; Tomlins, S.A.; Trau, M. Merging new-age biomarkers and nanodiagnostics for precision prostate cancer management. Nat. Rev. Urol. 2019. [CrossRef] [PubMed]

211. Downing, A.; Wright, P.; Hounsome, L.; Selby, P.; Wilding, S.; Watson, E.; Wagland, R.; Kind, P.; Donnelly, D.W.; Butcher, H.; et al. Quality of life in men living with advanced and localised prostate cancer in the UK: A population-based study. Lancet Oncol. 2019, 20, 436-447. [CrossRef]

212. Arora, V.K.; Schenkein, E.; Murali, R.; Subudhi, S.K.; Wongvipat, J.; Balbas, M.D.; Shah, N.; Cai, L.; Efstathiou, E.; Logothetis, C.; et al. Glucocorticoid receptor confers resistance to antiandrogens by bypassing androgen receptor blockade. Cell 2013, 155, 1309-1322. [CrossRef]

213. Sorrentino, G.; Ruggeri, N.; Zannini, A.; Ingallina, E.; Bertolio, R.; Marotta, C.; Neri, C.; Cappuzzello, E.; Forcato, M.; Rosato, A.; et al. Glucocorticoid receptor signalling activates YAP in breast cancer. Nat. Commun. 2017, 8, 1-14. [CrossRef] [PubMed]

214. Fu, D.; Lv, X.; Hua, G.; He, C.; Dong, J.; Lele, S.M.; Li, D.W.-C.; Zhai, Q.; Davis, J.S.; Wang, C. YAP regulates cell proliferation, migration, and steroidogenesis in adult granulosa cell tumors. Endocr. Relat. Cancer 2014, 21, 297-310. [CrossRef] [PubMed]

215. Bonkhoff, H. Estrogen receptor signaling in prostate cancer: Implications for carcinogenesis and tumor progression. Prostate 2018, 78, 2-10. [CrossRef] [PubMed]

216. Di Zazzo, E.; Galasso, G.; Giovannelli, P.; Di Donato, M.; Castoria, G. Estrogens and Their Receptors in Prostate Cancer: Therapeutic Implications. Front. Oncol. 2018, 8, 1-7. [CrossRef] [PubMed]

217. Risbridger, G.P.; Davis, I.D.; Birrell, S.N.; Tilley, W.D. Breast and prostate cancer: More similar than different. Nat. Rev. Cancer 2010, 10, 205-212. [CrossRef] [PubMed]

(C) 2019 by the authors. Licensee MDPI, Basel, Switzerland. This article is an open access article distributed under the terms and conditions of the Creative Commons Attribution (CC BY) license (http://creativecommons.org/licenses/by/4.0/). 